RESULTS OF QUALIFICATION TESTS ON

WATER-LEVEL SENSING INSTRUMENTS, 1987

By Truth E. Olive

U.S. GEOLOGICAL SURVEY

Open-File Report 89-397 


\section{DEPARTMENT OF THE INTERIOR \\ MANUEL LUJAN, JR., Secretary \\ U.S. GEOLOGICAL SURVEY}

Dallas L. Peck, Director

For additional information, write to:

Chief

Hydrologic Instrumentation Facility

U.S. Geological Survey

Building 2101

Stennis Space Center, MS 39529
Copies of this report can be purchased from:

U.S. Geological Survey Books and Open-File Reports Section Federal Center, Bldg. 810

Box 25425

Denver, Colorado 80225 
Abstract ........................ . . . . . . 1

Introduction ........................ 1

Purpose and scope . . . . . . . . . . . . . . . . 2

Acknowledgments . . . . . . . . . . . . . . . . . . 2

Description of instrument systems tested and special installation requirements . . . . . . . . . . . . . . . . . . . 2

Leupold and Stevens PG-III pulse generator, Telemark II encoder, and environmental modem system . . . . . . . . . . 4

Endeco model 1029 solid-state memory water-level recorders . 7

Test procedures . . . . . . . . . . . . . . . . . 11

Test results . . . . . . . . . . . . . . . . . 12

Conclusions . . . . . . . . . . . . . . . . . . . . . 27

Selected references .. . . . . . . . . . . . . . . . 29

Glossary . . . . . . . . . . . . . . . . . . . . . . 30

Appendix I--Reprint of comparison of instrument system

features from the three previous Qualified Products List

reports on water-level sensing instruments . . . . . . . . . . 31

Appendix II--Qualified Products List for water-level sensing

instruments, October 1987 . . . . . . . . . . . . . . . . 36

Appendix III--System accuracy for daily-discharge and special-

case stations .................. . . . . 37

\section{ILLUSTRATIONS}

Figures 1-4. Photographs of:

1. Leupold and Stevens PG-III pulse generator . . . . . . 4

2. Leupold and Stevens Telemark II encoder and the environmental modem .. . . . . . . . . . . . 5

3. Endeco model 1029 solid-state memory water-level recorder system . . . . . . . . . . . . . . 7

4. Endeco mode1 1029 solid-state memory water-leve1 recorder system, closed, as it appears in field use 8

Figures 5-8. Graphs showing:

5. Observed error of the Leupold and Stevens system over the qualification temperature range from -38 to

6. Observed error of the Endeco model 1029 solid-state memory water-level recorder surface electronics unit over the qualification temperature range from -38 to $65{ }^{\circ} \mathrm{C}$. . . . . . . . . . . . .

7. Output stability of the Endeco model 1029 solid-state memory water-level recorder system over a 24-hour period . . . . . . . . . . . . . .

8. Temperature effects on the Endeco model 1029 solidstate memory water-1eve1 recorder subsurface unit 
Table 1. Physical and performance characteristics of

Page instrument systems................ . 3

2. Test results of Leupold and Stevens system . . . . . . 13

3. Test results of the Endeco model 1029 solid-state memory water-level recorder, May 21, 1987 . . . . . . . .

4. Test results of the Endeco model 1029 solid-state memory water-level recorder, September 2, 1987 . . . . . .

5. Drift of the Endeco model 1029 solid-state memory waterlevel recorder...................

6. The observed error of the Endeco model 1029 solid-state memory water-level recorder surface electronics unit over the qualification temperature range . . . . . . .

7. Output stability of the Endeco model 1029 solid-state memory water-level recorder system over a 24-hour period ....................

8. Test results of the Endeco model 1029 solid-state memory water-leve1 recorder, May 21, 1987 . . . . . . . . .

9. Test results of the Endeco model 1029 solid-state memory water-level recorder, May 28, 1987 . . . . . . . . . .

10. Test results of the Endeco model 1029 solid-state memory water-1eve1 recorder, May 29, 1987 . . . . . . . . .

11. Test results of the Endeco model 1029 solid-state memory water-level recorder, June 2, 1987 ......... 


\section{CONVERSION FACTORS}

The inch-pound units used in this report may be converted to metric (International System) units by the following factors:

Multiply inch-pound unit

To obtain metric unit

foot (ft)

0.3048

meter (m)

Temperature in degrees Celsius $\left({ }^{\circ} \mathrm{C}\right)$ may be converted to degrees Fahrenheit $\left({ }^{\circ} \mathrm{F}\right)$ as follows:

$$
\left({ }^{\circ} \mathrm{F}\right)=1.8\left({ }^{\circ} \mathrm{C}\right)+32
$$

\section{ABBREVIATIONS}

Abbreviations used in this report other than those given above are as follows:

$\begin{array}{ll}\text { ac } & \text { Alternating current } \\ \text { Ah } & \text { Ampere hour } \\ \text { dc } & \text { Direct current } \\ \text { EPROM } & \text { Electrically programmable read-only memory } \\ \text { F } & \text { Float } \\ \text { HIF } & \text { Hydrologic Instrumentation Facility } \\ \text { L\&S } & \text { Leupold and Stevens } \\ \text { QPL } & \text { Qualified Products List } \\ \text { SPT } & \text { Submersible pressure transducer } \\ \text { V } & \text { Volt }\end{array}$




\title{
RESULTS OF QUALIFICATION TESTS ON WATER-LEVEL SENSING INSTRUMENTS, 1987
}

By Truth E. Olive

\begin{abstract}
The U.S. Geological Survey's Hydrologic Instrumentation Facility at the Stennis Space Center, Mississippi, conducts qualification tests on water-leve1 sensing instruments. Instrument systems, which meet or exceed the Survey's minimum performance requirements, are placed on the Survey's Qualified Products List.

The qualification tests conducted in 1987 added two instrument systems to the Survey's Qualified Products List. One system met requirements for use at a daily-discharge station, and the other system met requirements for a special-case station.

This report is prepared for users of hydrologic instruments. This report provides a list of instrument features, describes the instrument systems, summarizes test procedures, and presents test results for the two instrument systems that met the Survey's minimum performance standards for the 1987 round of qualification tests.
\end{abstract}

\section{INTRODUCTION}

The U.S. Geological Survey conducts a nationwide program of waterresources surveys, investigations, and research. Over the years, the need for streamflow and ground-water-level information has led the Survey to establish thousands of gaging stations on rivers, canals, streams, lakes, reservoirs, and observation-well sites. The most common methods of measuring water-surface elevation or stage are with floats and manometers. Stage is sensed, either by a float in a stilling well or by a gas-purge system that transmits the pressure head of water in a stream to a manometer. The latter system, which does not require a stilling well, is commonly known as a bubble gage (Rantz and others, 1982). The stage from either system may then be mechanically or electronically recorded by other instrumentation.

Hydrologic-instrument manufacturers continually develop new systems to sense and record water-level data. Two systems--the Leupold \& Stevens water-level sensing system, consisting of the PG-III pulse generator, Telemark II encoder, and the environmental modem, and the Endeco mode1 1029

1 Use of trade names in this report is for identification purposes only and does not constitute endorsement by the U.S. Geological Survey. 
solid-state memory water-level system--were tested in 1987 at the Hydrologic Instrumentation Facility (HIF). The purpose of this testing was to determine whether the systems could meet the Survey's minimum performance requirements for the collection of water-level data (Buchanan and Somers, 1968; Kennedy, 1983; and Rapp, 1982). This report, the fourth in the series on water-level sensing instruments, summarizes the test results and describes the two instrument systems that met or exceeded the minimum qualifying standards.

The Survey's Hydrologic Instrumentation Facility, Stennis Space Center, Mississippi, conducts qualification tests on various hydrologic instrumentation. Under the Qualified Products List (QPL) program, waterlevel sensing systems are tested by the HIF. Systems that pass the qualification tests are placed on the Survey's QPL. The Federal Acquisition Regulations (General Services Administration, 1984) allow Federal agencies to require manufacturers to have their products tested and qualified for the QPL before these manufacturers may submit bids in response to a solicitation for bids by the agencies. The QPL can be used as a guide by the Survey's field offices when purchasing systems that are not available from the HIF.

The tables, which were published in the previous Results of Qualification Tests on Water-Level Sensing Instruments reports and listed the features of the instruments that were tested, are included in appendix I. A glossary is included in this report to aid in understanding the terminology used.

\section{Purpose and Scope}

This report provides the users of water-level sensing instruments a description of the two instrument systems tested in 1987, a list of instrument features, a description of test procedures, and test results. The report does not make recommendations as to the best instrument system for any given application. The report does, however, provide pertinent information and test results on the two instrument systems tested and a summary of test results for instruments described in previous reports in this series. This information can assist the reader in selecting a system that meets the requirements of a particular site or the data needed.

\section{Acknowledgments}

The author acknowledges the cooperation of the instrument manufacturers who provided the instrument systems for the qualification tests.

\section{DESCRIPTION OF INSTRUMENT SYSTEMS TESTED AND SPECIAL INSTALIATION REQUIREMENTS}

One model of each instrument system was tested. These instruments are available from the manufacturers. Manufacturers' names and addresses are listed in appendix II. System accuracy for daily-discharge and special-case stations is provided in appendix III. A comparison of major system features is given in table 1 . 
Table 1.--Physical and performance characteristics of instrument systems

\begin{tabular}{|c|c|c|}
\hline \multirow[b]{2}{*}{ Selected instrument features } & \multicolumn{2}{|c|}{ Instrument company, model name, and number } \\
\hline & $\begin{array}{l}\text { Leopold \& Stevens } \\
\text { PG-III pulse generator } \\
\text { Telemark II encoder, and } \\
\text { environmental modem }\end{array}$ & $\begin{array}{l}\text { Endeco model } 1029 \\
\text { solid-state } \\
\text { memory water- } \\
\text { level recorder }\end{array}$ \\
\hline Station type (appendix III) & daily-discharge & special-case \\
\hline $\begin{array}{l}\text { System error: } \\
\text { System difference from } \\
\text { standard reference, in feet }\end{array}$ & 0.00 & -0.164 to -0.145 \\
\hline $\begin{array}{l}\text { Sensor type: } \\
\text { float (F) } \\
\text { submersible pressure } \\
\text { transducer (SPT) }\end{array}$ & $\mathbf{F}$ & SPT \\
\hline Stilling well required & yes & no \\
\hline $\begin{array}{l}\text { Maximum cable length from } \\
\text { generator to encoder box } \\
\text { recommended range in water- } \\
\text { level, in feet }\end{array}$ & 0 to 999 & 50 \\
\hline Affected by sediment & yes & yes \\
\hline $\begin{array}{l}\text { Power requirement, in } \\
\text { volts, dc, ac }\end{array}$ & $\begin{array}{l}8 \text { to } 15 \mathrm{~V} \mathrm{dc} \text {; } \\
12 \mathrm{~V} \text { dc, } 8 \mathrm{Ah} \text { gelled } \\
\text { electrolyte lead-acid } \\
\text { battery is recommended } \\
\text { (external) }\end{array}$ & $\begin{array}{l}12 \text { V dc; } \\
8 \text { D-size } \\
\text { alkaline } \\
\text { batteries } \\
\text { (internal) }\end{array}$ \\
\hline $\begin{array}{l}\text { Instrument weight, } \\
\text { in pounds }\end{array}$ & 7.0 & 11.5 \\
\hline $\begin{array}{l}\text { Instrument size } \\
\text { (see glossary) }\end{array}$ & A & A \\
\hline Shelter required & yes & no \\
\hline $\begin{array}{l}\text { Operating range in air } \\
\text { temperature, in degrees } \\
\text { Celsius }\end{array}$ & -40 to 65 & $\begin{array}{l}-20 \text { to } 45 \\
\text { surface unit } \\
-5 \text { to } 45 \\
\text { subsurface unit }\end{array}$ \\
\hline Internal data memory & yes & yes \\
\hline Data output & $\begin{array}{l}\text { digital ASCII } \\
\text { RS } 232 \mathrm{C} \text { to local computer } \\
\text { or through modem to remote } \\
\text { computer or telephone }\end{array}$ & $\begin{array}{l}\text { memory cartridge; } \\
\text { RS } 232 \mathrm{C} \text { to } \\
\text { local computer; } \\
\text { through modem } \\
\text { to telephone or } \\
\text { remote computer; } \\
\text { radio frequency; } \\
\text { or satellite }\end{array}$ \\
\hline
\end{tabular}




\section{Leupold and Stevens PG-III Pulse Generator. Telemark II Encoder, and Environmental Modem System}

The Leupold and Stevens (L\&S) system is a microprocessor-based, small, battery-operated, water-level sensing and transmitting system as shown in figures 1 and 2: The system has three components: pulse generator, encoder, and modem. The stand-alone PG-III pulse generator, operates with an 18-inch-circumference pulley and beaded cable or float tape. The Stevens PG-III pulse generator operates properly with all standard HIF-supplied float and counterweight systems when installed in a stilling well. The PG-III pulse generator detects water levels or rainfall or both. It can be used by itself or in conjunction with a Fischer and Porter recorder, a Stevens type A recorder, or Belfort-type weighing bucket rainfall recorder. The pulse generator is enclosed in a metal case measuring 5 by 5 by 5.25 inches and weighs 4 pounds.

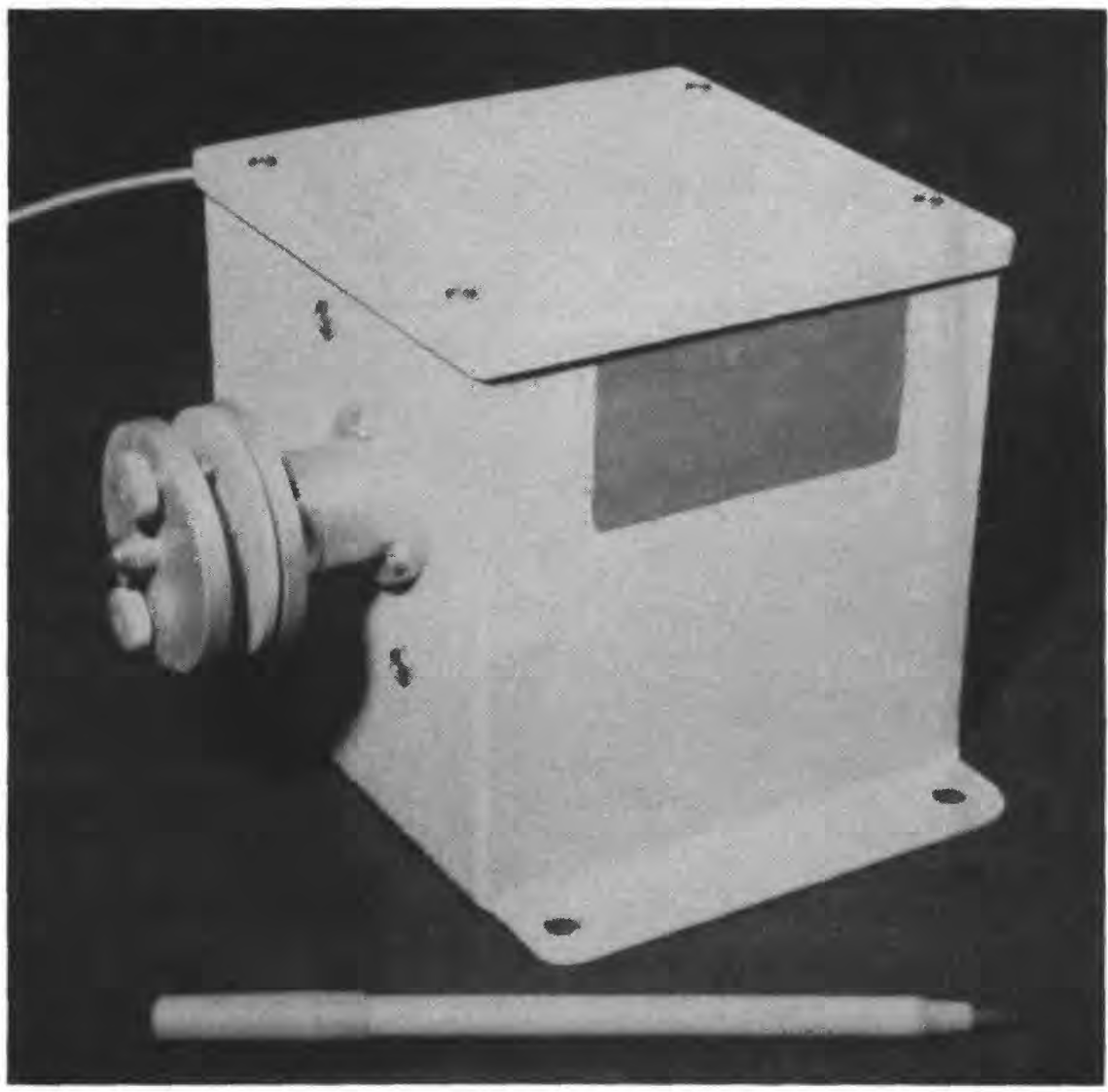

Figure 1.--Leupold and Stevens PG-III pulse generator. 


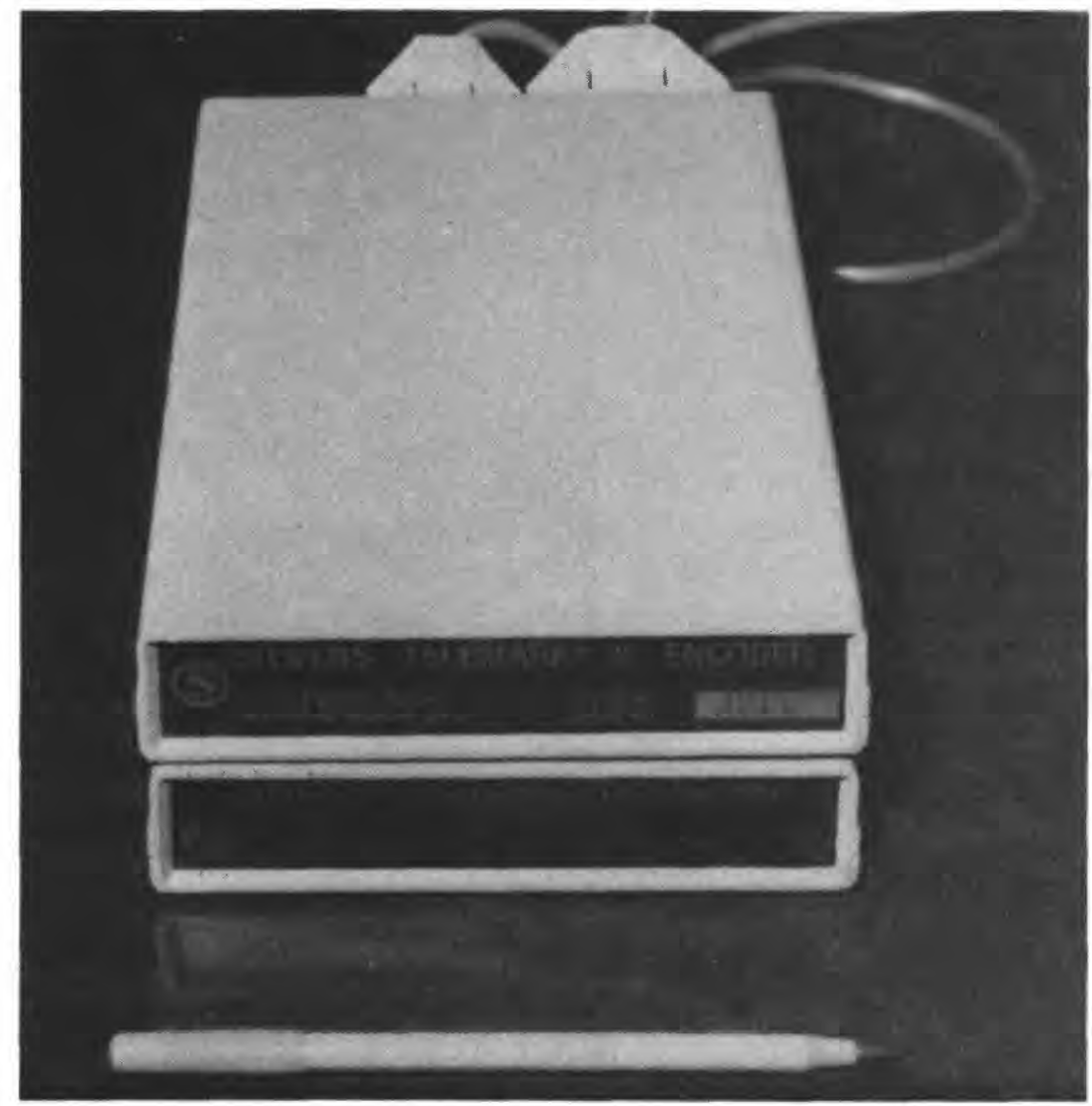

Figure 2.--Leupold and Stevens Telemark II encoder and the environmental modem.

The Telemark II encoder model 8503 is a recorder that processes the pulses from the PG-III pulse encoder to determine the water-level elevation and stores the elevation data in solid-state memory. The environmental modem connects the Telemark II encoder to a telephone line for telemetry of the data. The dimensions of the Telemark II encoder and the environmental modem cases are 6.3 by 9.5 by 1.5 inches. Each weighs 1.5 pounds. The encoder and modem cases are molded plastic and conductively coated for control of electromagnetic interference and protection from electrostatic discharge. A shelter and a stilling well are required for this system.

The signal from the PG-III pulse generator can be sent to a datacollection platform or the Telemark II encoder. The encoder can be interrogated and programmed in the field, using a portable computer. The software used by the L\&S system is resident in the Telemark II encoder. A portable computer can be used to display data values stored in memory. A portable printer can be taken to the field to get a print-out of data stored in memory. The encoder can be interrogated through the environmental modem by a remote telephone on manual dial-up for transmission of data in audible tones suitable for human interpretation or by a remote computer. Only the 
present water-level reading can be received by remote telephone. Computer interrogation is done by high-speed transmission using serial ASCII format. Several software packages for personal computers can be used to communicate with the modem from remote locations and create files for the storage of the historical data or obtain the most current reading. The software automatically selects the correct transmission format.

The environmental modem is designed for use with RS-232C compatible devices. The modem uses standard telephone lines and wall jacks. The data input and power connector on the encoder is a single 15-pin " $D$ " connector. A 25-pin " $D$ " connector cable is used for serial communications from the encoder to the modem or portable computer. The modem is a 300-bit-persecond (baud) asynchronous modem registered by the Federal Communications Commission (1986), Part 68. It is certified for direct connection to the telephone network. The required telephone line connector is either an RJ11C, RJ12C, or RJ13C. The encoder and modem are Federal Communication Commission classified Class A computing devices. Therefore, the operation of this equipment in a residential area may cause unacceptable interference to radio and TV reception, requiring that the Telemark II system installer take the steps necessary to eliminate or minimize the interference. The environmental modem is an answer-only modem. It does not require external phone-line transient protection because it has built-in transient protection. The encoder has two input channels for water-level or precipitation data from pulse generators or tilting-bucket rain gages. The encoder's range for water levels is 000.00 to 999.99 feet and for precipitation is 00.00 to 99.99 inches. The resolution is 0.005 foot with the read-out two places to the right of the decimal point. The recording intervals, which are selectable, are 15, 30, and 60 minutes or 4, 12, and 24 hours. The encoder's nonvolatile memory will store up to 800 readings. At a recording interval of 60 minutes, it will store 33 days of record for a single input or it will store 21 days of record for a dual input. At a recording interval of 24 hours, it will store 800 days of record for a single input or it will store 500 days of record for dual input. For dual input, only one date tag identifier is needed for two inputs.

The three components can be operated from the same external 12-volt battery. In this configuration, the modem-power connection is through the cable that connects the encoder and modem. An optional ac-to-dc power converter is available for the modem. The Telemark II encoder standby current is typically 500 microamperes and, during data transmission, the operating current is 14 milliamperes. The environmental modem standby current is typically 10 microamperes and, during data transmission, the operating current is 40 milliamperes. This system will operate for 6 months on one rechargeable, lead-acid, 12-volt, 8-ampere-hour battery before the battery is pulled down to the 50-percent capacity level of 12 volts. This is based on a once-a-day total memory dump, lasting 5 minutes, from a remote terminal. A twice-a-day present reading interrogation requires less power.

The qualification temperature range is -38 to $65{ }^{\circ} \mathrm{C}$ and 0 - to 100-percent relative humidity, condensing. The manufacturer states the temperature range as -40 to $71{ }^{C}$ and 0 - to 95 -percent noncondensing relative humidity. The circuit boards are conformably coated to protect the components from moisture. The modem has built-in, lightning-voltage spike protection, which must be properly grounded to earth with the grounding wire provided by the manufacturer. The L\&S PG-III pulse generator has special control logic, which negates the effects of waves and ripples on the water surface in the stilling well. 


\section{Endeco Mode1 1029 Solid-State Memory Water-Leve1 Recorders}

The Endeco model 1029 solid-state memory (SSM) water-leve1 recorder is a microprocessor-based, battery-operated water-level sensing and recording system as shown in figures 3 and 4 . The Endeco solid-state system measures and records the pressure of the column of water above the subsurface sensor unit. The depth measured is relative to the center of the strain-gage sensor. The system consists of a surface electronic recording unit and a subsurface sensor unit, which are connected by a permanent 50 -foot-long, urethane-jacketed cable. The cable encloses four wires and a vent tube.

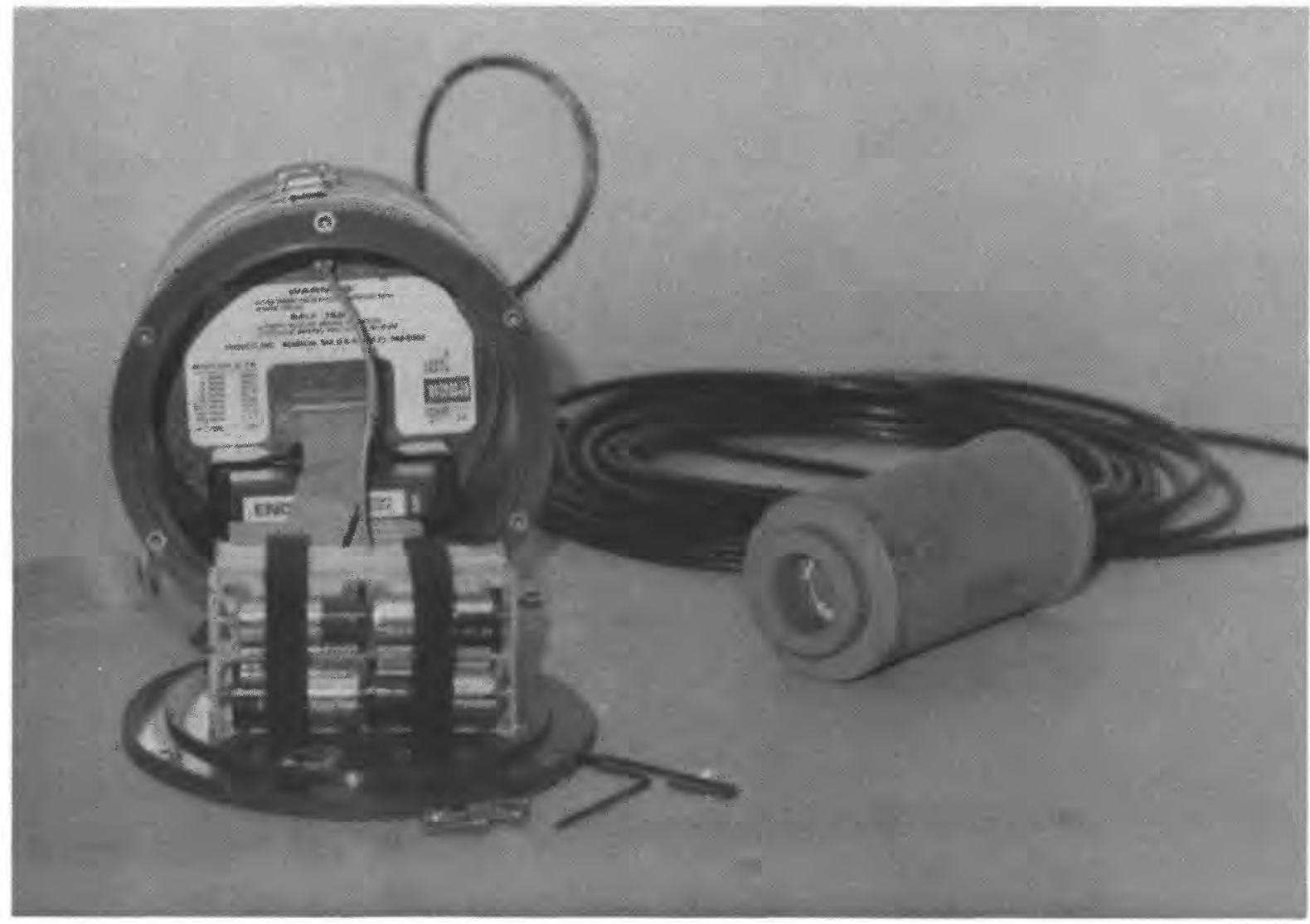

Figure 3.--Endeco model 1029 solid-state memory water-level recorder system. Left: Surface electronic recording unit, opened, showing batteries in cover.

Right: Subsurface sensor unit and 50-foot-long, urethanejacketed cable.

1 The Endeco subsurface sensor unit can be used only to a water depth of 50 feet and maintain the accuracy for the special-case station.

Additional extension cables may be purchased from Endeco if longer surface cable lengths are needed to connect the surface and subsurface units. 


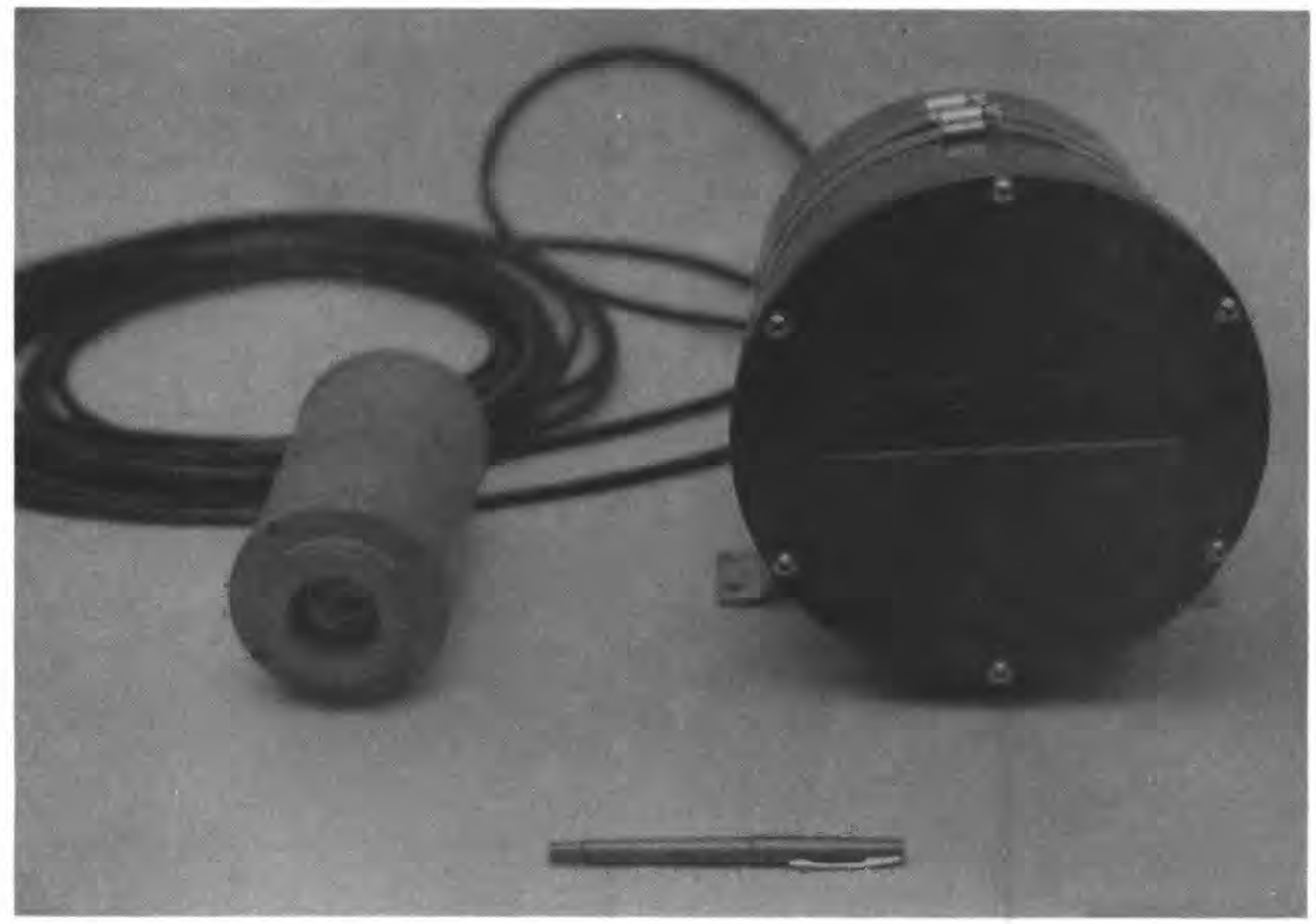

Figure 4.--Endeco model 1029 solid-state memory water-level recorder system, closed, as it appears in field use.

The surface and subsurface sensor units are constructed of molded urethane. The subsurface sensor unit is factory sealed and cannot be opened. The surface unit is opened by removing six screws. The electronics in the surface unit, which contains the sample-rate-setting dip switches, batteries, and memory cartridge, are protected from moisture by a desiccant and an 0-ring seal. The system consisting of the subsurface sensor unit, 50 feet of cable, and the surface recording unit weighs 11.5 pounds. The subsurface sensor unit dimensions are 7.25 inches long and 3.63 inches in diameter. The surface electronics unit dimensions are 7.87 inches long and 8.6 inches in diameter.

Water exerts pressure on a strain-gage pressure transducer located in the subsurface sensor unit. The output of the strain-gage pressure transducer is converted to a frequency proportional to the water pressure. The vented cable automatically compensates for variations in barometric (atmospheric) pressure; thus, the 1029 system only measures the pressure caused by the water above it. A thermistor bead bonded to the strain gage is used to compensate for temperature effects on the strain-gage transducer. Periodically during each sampling minute, the 1029 surface unit measures the frequency from the thermistor bead and uses the information to compensate for the effect of temperature on the strain-gage pressure sensor. 
The surface unit does not need to be placed in a gage house, but it is strongly recommended that it be securely mounted to a sturdy structure, such as a piling, with the optional mounting bracket that can be ordered with it. It should be mounted horizontally to prevent water from getting into the case when the memory cartridge is changed in the rain. The Endeco logo on the cover needs to be right side up so that the self-draining vent capillary accumulator and vent filter will work properly. The vented cable should never be clamped, kinked, or pinched. If the vent tube in the cable is pinched, the strain-gage pressure transducer will not be able to correctly sense atmospheric pressure.

The subsurface sensor unit should be mounted in a horizontal position just below the minimum water-level elevation and securely attached to a structure that will not move. If the subsurface sensor unit is mounted with the sensor end down, air bubbles can be trapped against the sensor and cause it to take incorrect readings. If it is mounted with the sensor end up, sediment from the water can collect on it and cause it to take incorrect readings.

The Endeco model 1029 SSM water-level recorder can be used as a standalone recording device where the data are stored in the memory cartridge or it can be used as a real-time data telemetry device where the data are transmitted through the RS-232C link by way of satellite, radio frequency, or telephone modem to an IBM-compatible personal computer.

When the 1029 SSM water-level recorder is used as a stand-alone recording device, data are recorded on a removable solid-state EPROM cartridge, capable of storing 32,650 water-level samples. The sampling intervals, which can be set using the dip switches, are $1,2,5,10,15,20$, 30 , or 60 minutes. If a sample interval of 1 minute is selected, the memory cartridge will be full in 22 days. If a sample interval of 60 minutes is selected, the memory cartridge will not be full in 1 year. Each water level is recorded with its corresponding date and time. Because the memory cartridge requires no power, each sample is secure once the 1029 SSM has written it into the cartridge. The cartridge can be erased only by prolonged exposure to a powerful ultraviolet lamp, available commercially or from Endeco.

The data in the memory cartridge are unloaded to an IBM-PC/XT/AT or compatible computer data file using the Endeco model 1138 cartridge reader and the Endeco software package 10290PS. The software packages are MS-DOS compatible. An IBM-PC/XT/AT or compatible computer, using the Endeco software package 1029RPT, is used to generate a report. The report that is generated is displayed on the computer terminal and can be printed by a printer attached to the personal computer. The report format selection is menu driven. The units of the data value are user-selectable in feet, meters, or pounds per square inch. A datum offset is also user-selectable. The serial number of the water-level recorder, time and date of the reading, and value of the reading are printed. The beginning and ending times of the report can be selected, if a report of only a portion of the data in the file is desired. 
The software package to perform real-time data collection (1029PRF) on either the IBM or a Radio Shack TRS-80 model 100 is available also from Endeco. To use a terminal or portable computer in the field, a standard RS-232C cable is needed to connect to the 1029 SSM. This is identical to the cable that is used between the IBM computer and the 1138 cartridge reader. The cable needs a DB25 plug to socket connector. Pins 1, 2, 3, and 7 are used and pin 8 is jumpered to pin 20. These cables are available commercially or through Endeco.

The Endeco 1029 SSM water-level recorder uses eight D-size alkaline batteries to supply an input of 12 volts. When the memory cartridge is the data-collection device, the whole system requires 4 milliamperes during the sampling minute and 180 microamperes between samples. When connected to a terminal or computer, the whole system requires 4 milliamperes during sampling and 1 milliampere while not sampling. When using the memory cartridge, the eight alkaline batteries supply enough power to fill the cartridge with data. The batteries are located in the cover of the surface unit (fig. 4) and need to be replaced when the memory cartridge is replaced. The batteries will supply adequate power over the temperature range specified for the Endeco 1029 system. If the system supply voltage becomes low, the system will no longer record data but the data on the cartridge are saved. This prevents inaccurate data from being recorded on the memory cartridge due to low battery voltage.

The Endeco 1029 SSM water-level recorder can measure water level in fresh or salt water. The operating temperature range of the surface unit is -20 to $45{ }^{\circ} \mathrm{C}$ and of the subsurface unit, -5 to $45{ }^{\circ} \mathrm{C}$. The storage temperature range for the system is -34 to $65{ }^{\circ} \mathrm{C}$. The water-level depthmeasuring range is 0 to $50 \mathrm{feet}$, and the maximum depth the transducer can withstand without damage is 138.6 feet.

As with any pressure-transducer system, the accuracy deteriorates with time. The sensor needs to be kept clear of sand, debris, and aquatic growth and mounted so that the sensor does not move. The electronics in the system compensate for wave action of the water. The subsurface unit does not need a stilling well to damp the wave action of the water, but a stilling well will prevent the unit from being damaged by underwater debris and ice. The subsurface-unit case requires periodic repainting with antifouling paint to prevent marine growth on the case and biofouling of the sensors. How often this needs to be done depends on temperature and algae content of the water. Marine growth on the strain-gage pressure-transducer face reduces its accuracy. Caution: The water level measured by a pressure-transducer system is a function of the density of the water above the sensor. Dissolved minerals, salt, and sediment suspended in the water increase the density of the water and affect the accuracy of the measurement. 
The laboratory qualification tests were conducted by the HIF's Test and Evaluation Section, using one model of each candidate system. Upon receipt from the manufacturer, each system was unpacked, inspected for shipping damage, and set up in the laboratory according to the manufacturer's instructions. To assure that each instrument system was tested under the same conditions, all tests were run indoors under controlled conditions, which simulated average and extreme field conditions.

The first test on each system was made at prevailing room temperature and humidity conditions. This was a bench test to familiarize personnel with system operation and to test instrument output at a constant input. Auxiliary laboratory instruments, printers, and recorders for the tests were connected to each system during this period. The power consumption and stability of each system's output were monitored.

The calibration of each instrument was checked in the second test, using procedures appropriate for that type of system. A pressure standard was used to check the pressure transducer and a precision 360 -degree compass was used to check the shaft encoder.

Environmental tests were run to establish the system performance under simulated field conditions. The electronic instrument packages were placed in the environmental test chamber. The submersible pressure transducer package was placed in a water bath, and a controlled pressure was applied to the unit during testing. The tests were run under controlled temperature and humidity conditions.

The last test was a calibration check for drift in the instrument's output over the qualification testing period. The initial calibration procedures were repeated. 


\section{TEST RESULTS}

Torque-and-sensitivity test results for the Leupold and Stevens system showed no difference in torque at 25,65 , or $-40{ }^{\circ} \mathrm{C}$ (table 2). For the torque-and-sensitivity test and the accuracy test, the pulley was left on the pulse generator and a shaft extension was made so that the shaft on the pulse generator could be rotated manually from outside the chamber.

Test results for the Leupold and Stevens system at a constant temperature of $25 \pm 2{ }^{\circ} \mathrm{C}$, are given in table 2 . 
Table 2.--Test results of Leupold and Stevens system

(Calibration test was performed in a 5 -foot water column at $25 \pm 2{ }^{\circ} \mathrm{C}$.)

\begin{tabular}{|c|c|c|}
\hline$\frac{\text { Point gage }}{(\text { feet })}$ & $\frac{\text { System reading }}{(\text { feet })}$ & $\frac{\text { Difference }}{(\text { feet })}$ \\
\hline $\begin{array}{l}2.000 \\
2.010 \\
2.020 \\
2.030\end{array}$ & $\begin{array}{l}2.00 \\
2.01 \\
2.02 \\
2.03\end{array}$ & $\begin{array}{l}0 \\
0 \\
0 \\
0\end{array}$ \\
\hline $\begin{array}{l}2.040 \\
2.100 \\
2.200 \\
2.300\end{array}$ & $\begin{array}{l}2.04 \\
2.10 \\
2.20 \\
2.30\end{array}$ & $\begin{array}{l}0 \\
0 \\
0 \\
0\end{array}$ \\
\hline $\begin{array}{l}2.400 \\
2.500 \\
2.600 \\
2.700\end{array}$ & $\begin{array}{l}2.40 \\
2.50 \\
2.60 \\
2.70\end{array}$ & $\begin{array}{l}0 \\
0 \\
0 \\
0\end{array}$ \\
\hline $\begin{array}{l}2.800 \\
2.900 \\
3.000 \\
3.100\end{array}$ & $\begin{array}{l}2.80 \\
2.90 \\
3.00 \\
3.10\end{array}$ & $\begin{array}{l}0 \\
0 \\
0 \\
0\end{array}$ \\
\hline $\begin{array}{l}3.200 \\
3.300 \\
3.400 \\
3.500\end{array}$ & $\begin{array}{l}3.20 \\
3.30 \\
3.40 \\
3.50\end{array}$ & $\begin{array}{l}0 \\
0 \\
0 \\
0\end{array}$ \\
\hline $\begin{array}{l}3.400 \\
3.300 \\
3.200 \\
3.100\end{array}$ & $\begin{array}{l}3.40 \\
3.30 \\
3.20 \\
3.10\end{array}$ & $\begin{array}{l}0 \\
0 \\
0 \\
0\end{array}$ \\
\hline $\begin{array}{l}3.000 \\
2.900 \\
2.800 \\
2.700\end{array}$ & $\begin{array}{l}3.00 \\
2.90 \\
2.80 \\
2.70\end{array}$ & $\begin{array}{l}0 \\
0 \\
0 \\
0\end{array}$ \\
\hline $\begin{array}{l}2.600 \\
2.500 \\
2.400 \\
2.300 \\
2.200 \\
2.100 \\
2.040 \\
2.030\end{array}$ & $\begin{array}{l}2.60 \\
2.50 \\
2.40 \\
2.30 \\
2.20 \\
2.10 \\
2.04 \\
2.03\end{array}$ & $\begin{array}{l}0 \\
0 \\
0 \\
0 \\
0 \\
0 \\
0 \\
0\end{array}$ \\
\hline $\begin{array}{l}2.020 \\
2.010 \\
2.000\end{array}$ & $\begin{array}{l}2.02 \\
2.01 \\
2.00\end{array}$ & $\begin{array}{l}0 \\
0 \\
0\end{array}$ \\
\hline
\end{tabular}

The number of digits listed under each column for all tables does not imply that each digit is significant for a particular reading, but that several readings within the column do have this number of significant digits. 
Tables 3 and 4 show calibration test results and table 5 shows drift of the Endeco model 1029 SSM water-level recorder. The drift is over a 103-day period from May 21, 1987 (table 3) to September 2, 1987 (table 4). The drift is the September 2, 1987, difference in table 4 minus the May 21, 1987, difference shown in table 3 .

Table 3.--Test results of the Endeco model 1029 solid-state memory water-level recorder, May 21, 1987

(During the calibration test, the surface unit was at $25 \pm 2{ }^{\circ} \mathrm{C}$, and the subsurface sensor unit was in a water bath at a constant temperature of $35 \pm 0.2{ }^{\circ}$. The pressure was applied to the subsurface sensor unit, using the deadweight tester.)

\begin{tabular}{cccc}
\hline $\begin{array}{c}1 \text { Deadweight } \\
\text { tester } \\
\text { (feet) }\end{array}$ & $\begin{array}{c}\text { System } \\
\text { reading } \\
\text { (feet) }\end{array}$ & $\begin{array}{c}2 \text { Difference } \\
\text { (feet) }\end{array}$ & $\begin{array}{c}\text { Percent } \\
\text { difference } \\
\text { (percent) }\end{array}$ \\
\hline 0.000 & 0.005 & 0.005 & -- \\
0.333 & 0.340 & 0.007 & 2.1 \\
10.000 & 10.002 & 0.002 & 0.02 \\
20.000 & 19.995 & -0.005 & -0.02 \\
30.000 & 29.937 & -0.063 & -0.21 \\
40.000 & 39.965 & -0.035 & -0.09 \\
50.000 & 49.939 & -0.061 & -0.12 \\
55.000 & 54.931 & -0.069 & -0.12 \\
50.000 & 49.942 & & -0.12 \\
40.000 & 39.962 & -0.058 & -0.10 \\
30.000 & 29.969 & -0.038 & -0.10 \\
20.000 & 19.986 & -0.031 & -0.07 \\
10.000 & 10.006 & -0.014 & 0.06 \\
0.333 & 0.345 & 0.006 & 3.6 \\
0.000 & 0.010 & 0.012 & -- \\
\hline & & 0.010 & \\
\hline
\end{tabular}

1

A deadweight tester is a pressure standard for calibrating pressure transducers in which known pneumatic pressures are generated by means of freely balanced (dead) weights loaded on a calibrated ball.

2 Difference equals Endeco reading minus deadweight-tester reading. The negative sign indicates that the system tested recorded a value that was lower than the standard (deadweight tester). 
Table 4.--Test results of the Endeco model 1029 solid-state memory water-level recorder, September 2, 1987

(During the calibration test, the surface unit was at $25 \pm 2{ }^{\circ} \mathrm{C}$, and the subsurface sensor unit was in a water bath at a constant temperature of $35 \pm 0.2{ }^{\circ} \mathrm{C}$. The pressure was applied to the subsurface sensor unit using the deadweight tester.)

\begin{tabular}{cccc}
\hline $\begin{array}{c}1_{\text {Deadweight }} \\
\text { tester } \\
(\text { feet) }\end{array}$ & $\begin{array}{c}\text { System } \\
\text { reading } \\
\text { (feet) }\end{array}$ & $\begin{array}{c}\text { 2 } \\
\text { Difference } \\
\text { (feet) }\end{array}$ & $\begin{array}{c}\text { Percent } \\
\text { difference } \\
\text { (percent) }\end{array}$ \\
\hline 0.000 & 0.027 & 0.027 & -- \\
0.333 & 0.353 & 0.020 & 6.0 \\
10.000 & 10.022 & 0.022 & 0.22 \\
20.000 & 20.012 & 0.012 & 0.06 \\
30.000 & 29.999 & -0.001 & -0.003 \\
40.000 & 39.978 & -0.022 & -0.06 \\
50.000 & 49.957 & -0.043 & -0.09 \\
55.000 & 54.943 & -0.057 & -0.10 \\
50.000 & 49.954 & & -0.09 \\
40.000 & 39.972 & -0.046 & -0.07 \\
30.000 & 29.991 & -0.028 & -0.03 \\
20.000 & 20.006 & -0.009 & 0.03 \\
10.000 & 10.028 & 0.006 & 0.28 \\
0.333 & 0.367 & 0.028 & 10.21 \\
0.000 & 0.030 & 0.034 & -- \\
\hline
\end{tabular}

1

A deadweight tester is a pressure standard for calibrating pressure transducers in which known pneumatic pressures are generated by means of freely balanced (dead) weights loaded on a calibrated ball.

2

Difference equals Endeco reading minus deadweight-tester reading. The negative sign indicates that the system tested recorded a value that was lower than the standard (deadweight tester). 
Table 5.--Drift of the Endeco model 1029 solid-state memory water-level recorder

(The drift is over a 103-day period from May 21, 1987, to September 2, 1987. The drift is the September 2, 1987, difference in table 4 minus the May 21, 1987, difference shown in table 3.)

\begin{tabular}{ccc}
$\begin{array}{c}1_{\text {Difference }} \\
\text { May 21, 1987 } \\
\text { (feet) }\end{array}$ & $\begin{array}{c}\text { Difference } \\
\text { Sept. 2, 1987 } \\
\text { (feet) }\end{array}$ & $\begin{array}{r}\text { Drift } \\
\text { (feet) }\end{array}$ \\
\hline 0.005 & 0.027 & 0.022 \\
0.007 & 0.020 & 0.013 \\
0.002 & 0.022 & 0.020 \\
-0.005 & 0.012 & 0.017 \\
-0.063 & & \\
-0.035 & -0.001 & 0.062 \\
-0.061 & -0.022 & 0.013 \\
-0.069 & -0.043 & 0.018 \\
-0.058 & -0.057 & 0.012 \\
-0.038 & & 0.012 \\
-0.031 & -0.046 & 0.010 \\
-0.014 & -0.028 & 0.022 \\
0.006 & -0.009 & 0.020 \\
0.012 & 0.006 & 0.022 \\
0.010 & 0.028 & 0.022 \\
& 0.034 & 0.020 \\
\hline
\end{tabular}

1 Difference equals Endeco reading minus deadweight-tester reading. The negative sign indicates that the system tested recorded a value that was lower than the standard (deadweight tester).

2 Drift (stability) is the gradual shift or change in the output over a period of time due to change or aging of circuit components. 
Figure 5 shows the observed error for the Leupold and Stevens system over the qualification temperature range. The temperature-cycle test showed that the system performed satisfactorily during each of the tests. The modem was accessed through the telephone, and the system responded with a current reading each time. When the modem was accessed through a personal computer, using a commercially available communication program, the encoder was accessed and a current reading was received. Through use of a password, the encoder was placed in the command mode and the time, date, sampling interval, clear, date dump, and other commands were transmitted to the encoder; a data file was created and the memory of the encoder was transferred to it.

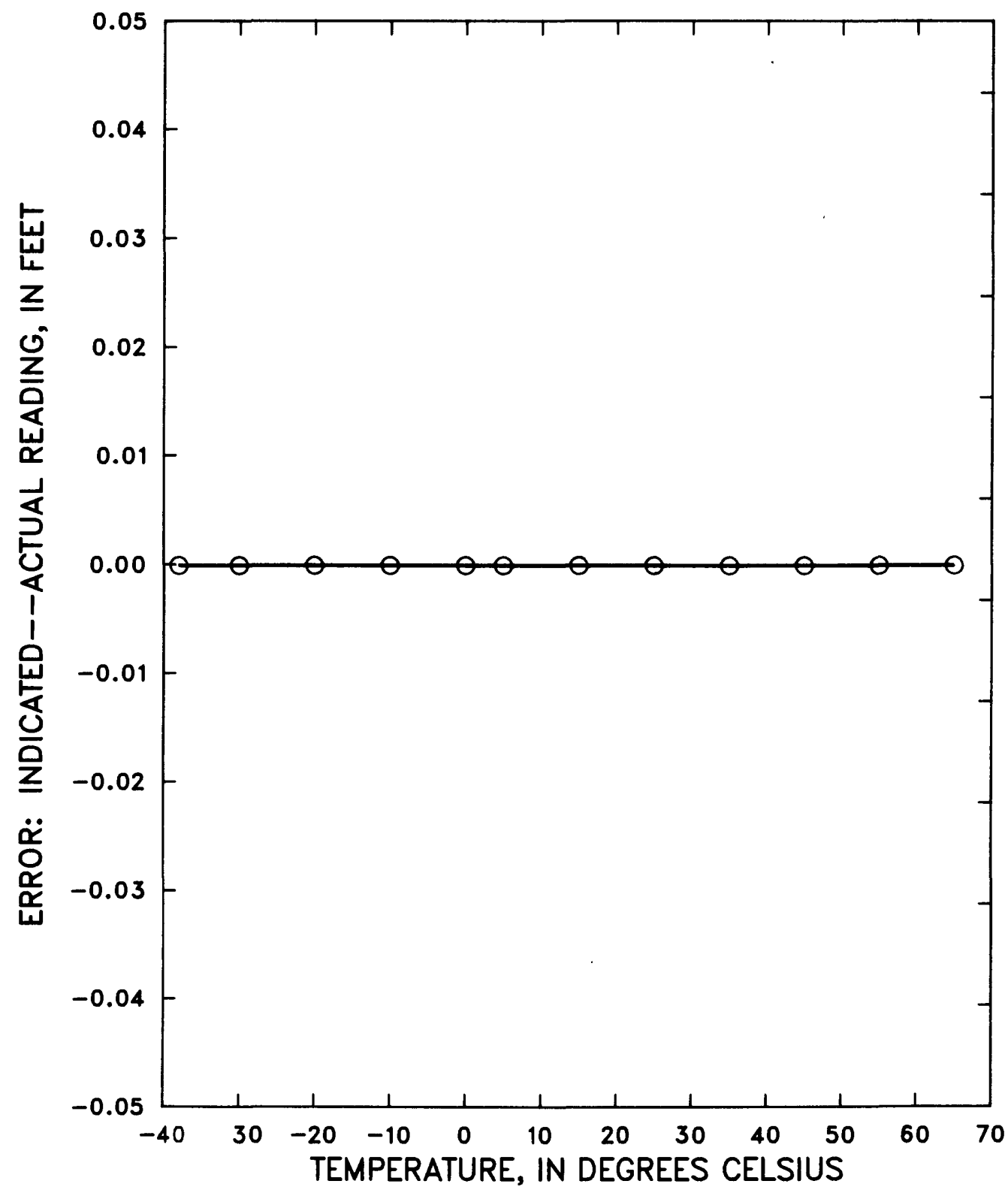

Figure 5.--Observed error of the Leupold and Stevens system over the qualification temperature range from -38 to $65{ }^{\circ} \mathrm{C}$. 
Figure 6 and table 6 show the observed error of the Endeco model 1029 SSM water-level recorder surface electronics unit over the qualification temperature range. The subsurface sensor unit was in a water bath with a constant temperature of $25 \pm 0.2{ }^{\circ} \mathrm{C}$ and a constant depth of $1 \pm 0.01$ foot of water.

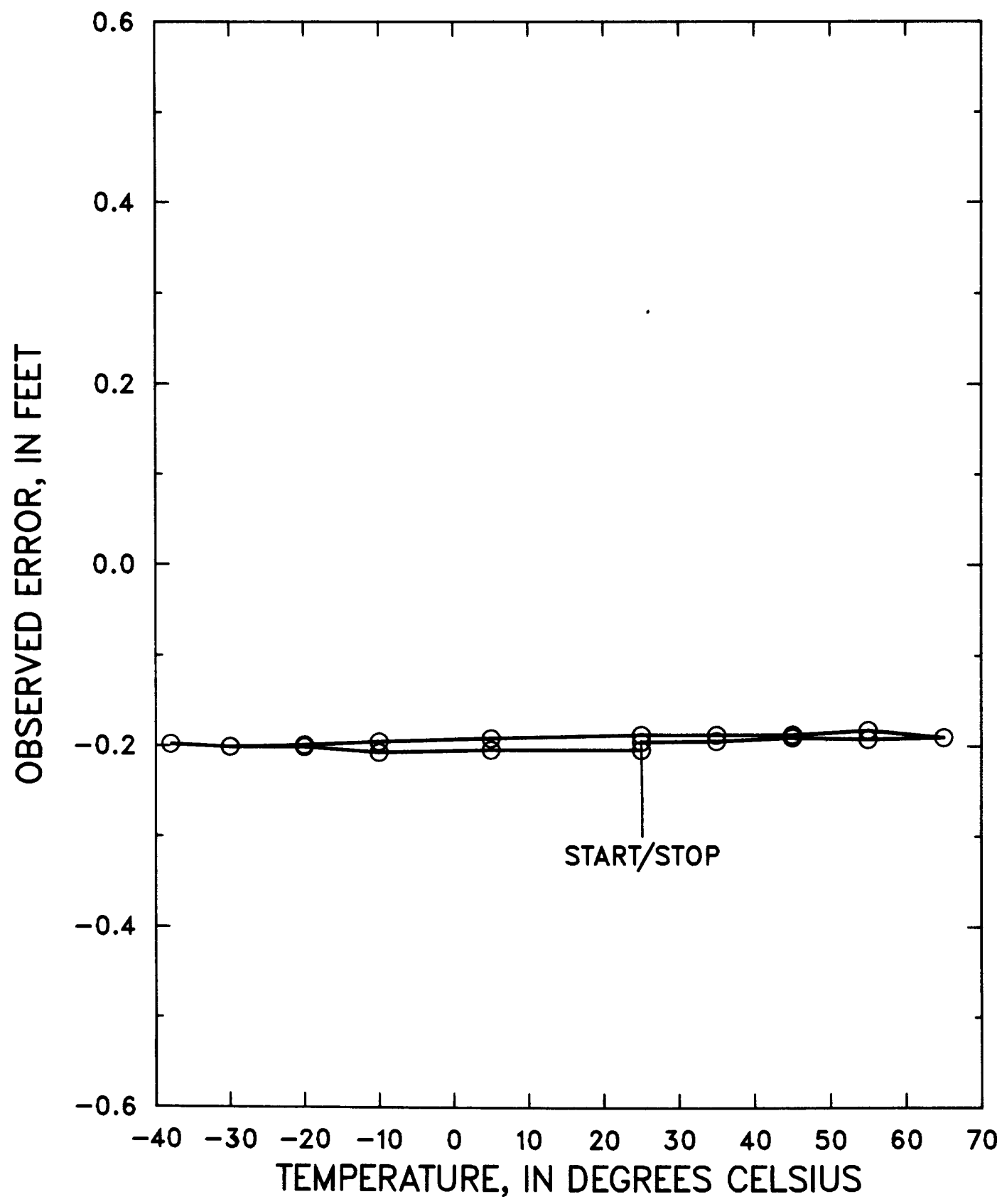

Figure 6.--Observed error of the Endeco model 1029 solid-state memory waterlevel recorder surface electronics unit over the qualification temperature range from -38 to $65{ }^{\circ} \mathrm{C}$. 
Table 6.--The observed error of the Endeco model 1029 solid-state memory water-level recorder surface electronics unit over the qualification temperature range

(The subsurface sensor unit was in a water bath with a constant temperature of $25 \pm 0.2{ }^{\circ} \mathrm{C}$ and a constant depth of $1 \pm 0.01$ foot of water.)

Environmental chamber temperature, in degrees Celsius

\begin{tabular}{|c|c|c|}
\hline $\begin{array}{l}\text { System } \\
\text { reading } \\
\text { (feet) }\end{array}$ & $\begin{array}{l}\text { Water } \\
\text { leve1 } \\
\text { (feet) }\end{array}$ & $\begin{array}{c}{ }^{1} \text { Difference } \\
(\text { feet })\end{array}$ \\
\hline
\end{tabular}

Percent difference (percent)

\begin{tabular}{rllll}
25 & 0.806 & 1.00 & -0.194 & -0.194 \\
35 & 0.807 & 1.00 & -0.193 & -0.193 \\
45 & 0.811 & 1.00 & -0.189 & -0.189 \\
55 & 0.809 & 1.00 & -0.191 & -0.191 \\
-65 & 0.811 & 1.00 & -0.189 & -0.189 \\
55 & 0.819 & 1.00 & -0.181 & -0.181 \\
45 & 0.814 & 1.00 & -0.186 & -0.186 \\
35 & 0.814 & 1.00 & -0.186 & -0.186 \\
25 & 0.814 & 1.00 & -0.186 & -0.186 \\
05 & 0.810 & 1.00 & -0.190 & -0.190 \\
-10 & 0.806 & 1.00 & -0.194 & -0.194 \\
-20 & 0.802 & 1.00 & -0.198 & -0.198 \\
-30 & & & & -0.200 \\
-38 & 0.800 & 1.00 & -0.200 & -0.197 \\
-30 & 0.803 & 1.00 & -0.197 & -0.200 \\
-20 & 0.800 & 1.00 & -0.200 & -0.200 \\
-10 & 0.800 & 1.00 & -0.200 & -0.206 \\
5 & & & & -0.203 \\
25 & 0.794 & 1.00 & -0.206 & -0.203 \\
\hline
\end{tabular}

1

Difference equals Endeco reading minus deadweight-tester reading. The negative sign indicates that the system tested recorded a value that was lower than the standard (deadweight tester). 
Figure 7 and table 7 show the output stability of the Endeco model 1029 SSM water-level recorder system over a 24-hour period. During the qualification test, the surface unit and subsurface unit were at $25 \pm 5{ }^{\circ} \mathrm{C}$. To determine output stability, the subsurface unit was in 3.000 feet of water. The instrument reading was recorded for 24 hours, and the observed instrument error was calculated.

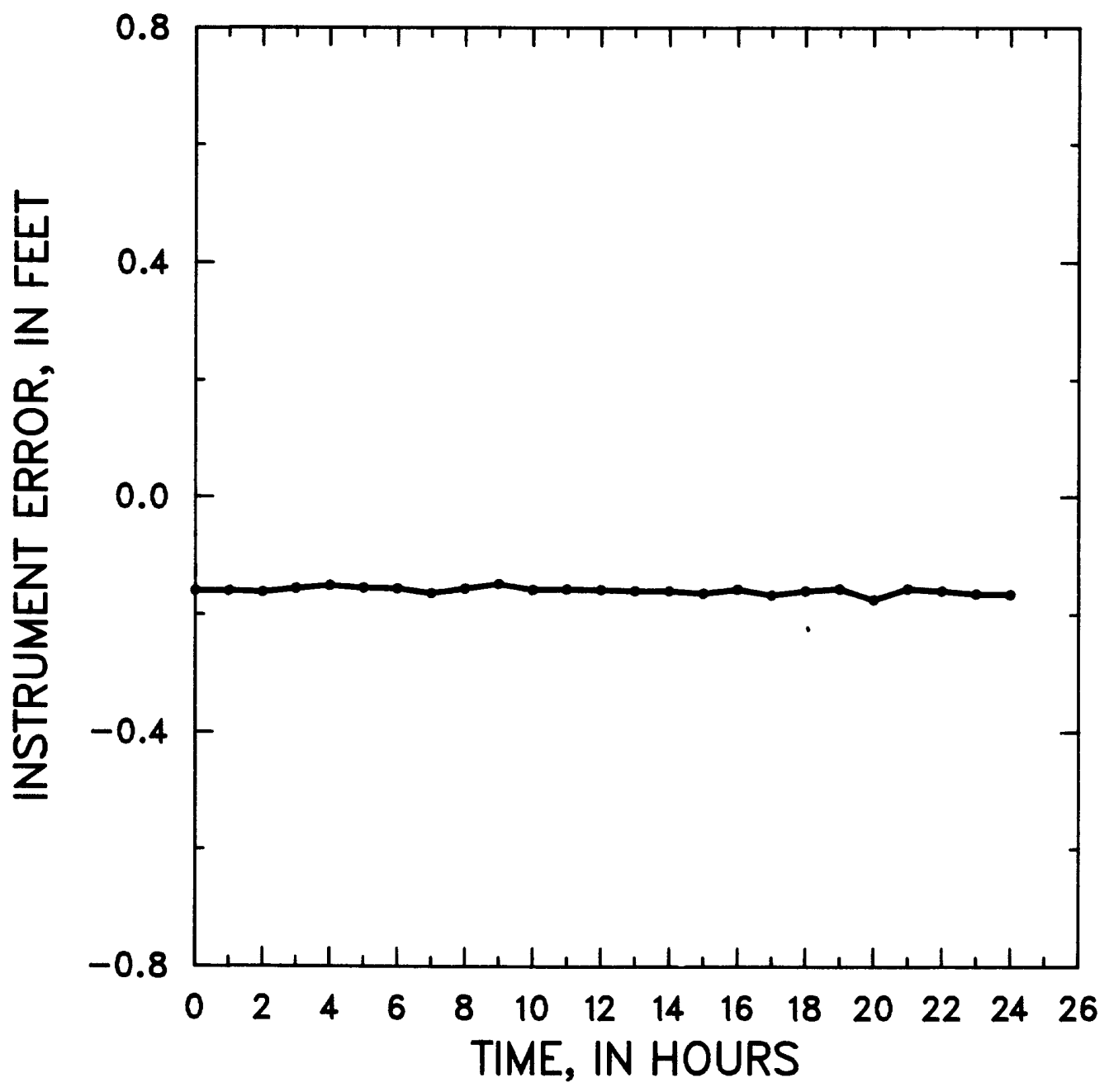

Figure 7.--Output stability of the Endeco model 1029 solid-state memory water-level recorder system over a 24 -hour period. 
Table 7.--Output stability of the Endeco model 1029 solid-state memory water-level recorder system over a 24-hour period

(During the qualification test the surface unit and subsurface unit were at $25 \pm 5{ }^{\circ} \mathrm{C}$. To determine output stability, the subsurface unit was in 3.000 feet of water. The instrument reading was recorded for 24 hours, and the observed instrument error was calculated.)

\begin{tabular}{|c|c|c|c|}
\hline $\begin{array}{l}\text { Time of } \\
\text { reading } \\
\text { (hour) }\end{array}$ & $\begin{array}{l}\text { System } \\
\text { reading } \\
\text { (feet) }\end{array}$ & $\begin{array}{l}\text { Water } \\
\text { level } \\
\text { (feet) }\end{array}$ & $\begin{array}{c}1_{\text {Difference }} \\
(\text { feet })\end{array}$ \\
\hline $\begin{array}{l}0 \\
1 \\
2 \\
3\end{array}$ & $\begin{array}{l}2.843 \\
2.843 \\
2.841 \\
2.847\end{array}$ & $\begin{array}{l}3.000 \\
3.000 \\
3.000 \\
3.000\end{array}$ & $\begin{array}{l}-0.157 \\
-0.157 \\
-0.159 \\
-0.153\end{array}$ \\
\hline $\begin{array}{l}4 \\
5 \\
6 \\
7\end{array}$ & $\begin{array}{l}2.852 \\
2.848 \\
2.847 \\
2.839\end{array}$ & $\begin{array}{l}3.000 \\
3.000 \\
3.000 \\
3.000\end{array}$ & $\begin{array}{l}-0.148 \\
-0.152 \\
-0.153 \\
-0.161\end{array}$ \\
\hline $\begin{array}{r}8 \\
9 \\
10 \\
11\end{array}$ & $\begin{array}{l}2.847 \\
2.855 \\
2.845 \\
2.846\end{array}$ & $\begin{array}{l}3.000 \\
3.000 \\
3.000 \\
3.000\end{array}$ & $\begin{array}{l}-0.153 \\
-0.145 \\
-0.155 \\
-0.154\end{array}$ \\
\hline $\begin{array}{l}12 \\
13 \\
14 \\
15\end{array}$ & $\begin{array}{l}2.845 \\
2.843 \\
2.843 \\
2.839\end{array}$ & $\begin{array}{l}3.000 \\
3.000 \\
3.000 \\
3.000\end{array}$ & $\begin{array}{l}-0.155 \\
-0.157 \\
-0.157 \\
-0.161\end{array}$ \\
\hline $\begin{array}{l}16 \\
17 \\
18 \\
19\end{array}$ & $\begin{array}{l}2.846 \\
2.836 \\
2.843 \\
2.847\end{array}$ & $\begin{array}{l}3.000 \\
3.000 \\
3.000 \\
3.000\end{array}$ & $\begin{array}{l}-0.154 \\
-0.164 \\
-0.157 \\
-0.153\end{array}$ \\
\hline $\begin{array}{l}20 \\
21 \\
22 \\
23 \\
24\end{array}$ & $\begin{array}{l}2.828 \\
2.847 \\
2.843 \\
2.838 \\
2.837\end{array}$ & $\begin{array}{l}3.000 \\
3.000 \\
3.000 \\
3.000 \\
3.000\end{array}$ & $\begin{array}{l}-0.172 \\
-0.153 \\
-0.157 \\
-0.162 \\
-0.163\end{array}$ \\
\hline
\end{tabular}

1

Difference equals Endeco reading minus deadweight-tester reading. The negative sign indicates that the system tested recorded a value that was lower than the standard (deadweight tester). 
Figure 8 and tables $8,9,10$, and 11 show the temperature effects on the Endeco model 1029 SSM water-level recorder subsurface unit. The difference is the instrument reading minus the actual depth applied by the deadweight tester. The Endeco model 1029 SSM water-level recorder surface unit was at a room temperature of $25 \pm 2{ }^{\circ} \mathrm{C}$. The Endeco subsurface sensor. unit was in a water bath at the noted temperature for each graph $\pm 0.2{ }^{\circ} \mathrm{C}$. At each test temperature, the deadweight tester water-level simulation was increased from 0 to 55 feet and then decreased to 0 feet. Zero to 50 feet is the operating range of the Endeco. The 55 feet of water is 10 percent over the measurement range specified by the manufacturer but within the overpressure range of the pressure transducer.

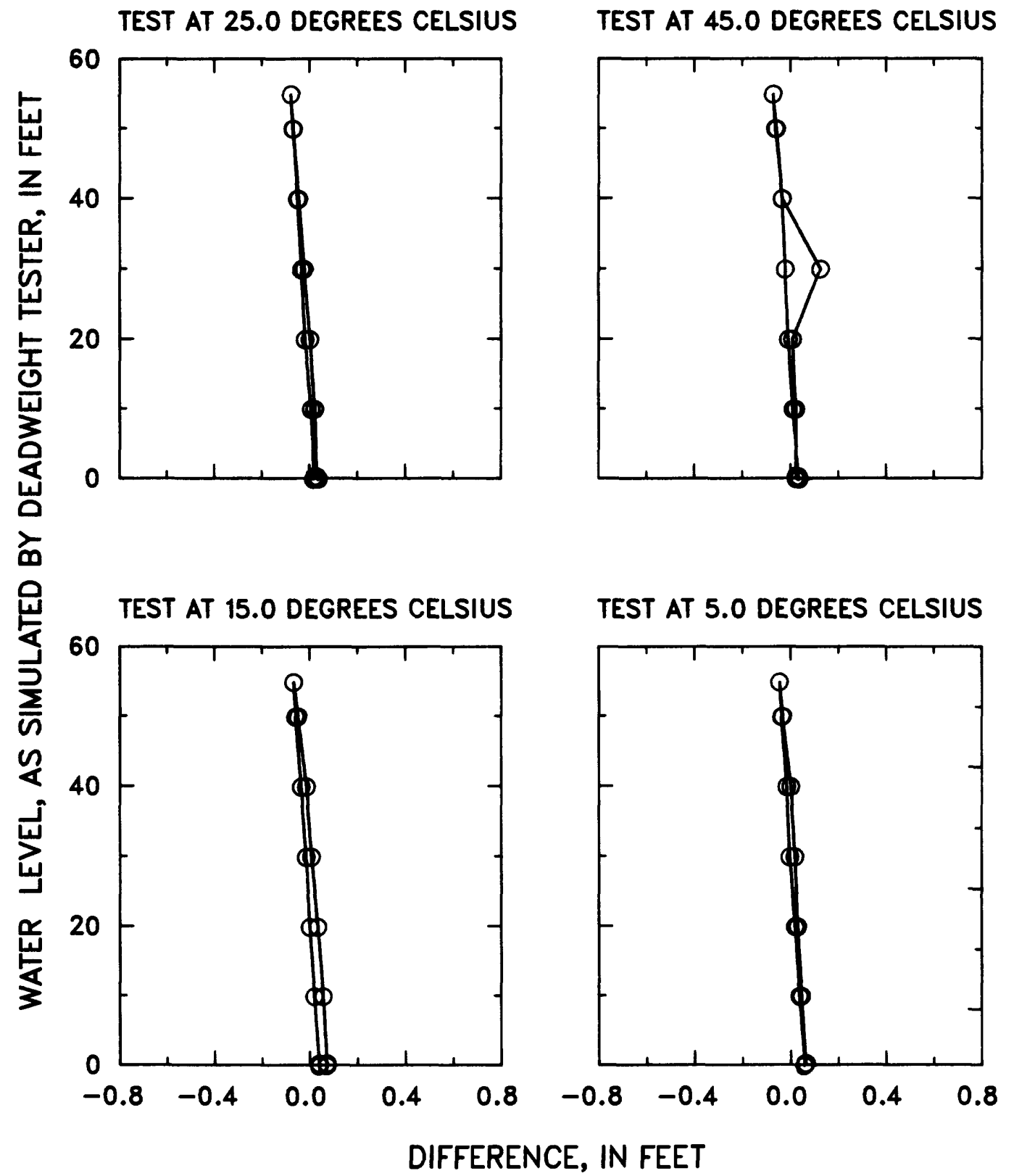

Figure 8.--Temperature effects on the Endeco model 1029 solid-state memory water-level recorder subsurface unit. 
Table 8.--Test results of the Endeco model 1029 solid-state memory water-level recorder, May 21, 1987

(During the calibration test, the surface unit was at $25 \pm 2{ }^{\circ} \mathrm{C}$, and the subsurface sensor unit was in a water bath at a constant temperature of $25 \pm 0.2{ }^{\circ} \mathrm{C}$. The pressure was applied to the subsurface sensor unit using the deadweight tester.)

\begin{tabular}{cccc}
\hline $\begin{array}{c}1 \text { Deadweight } \\
\text { tester } \\
\text { (feet) }\end{array}$ & $\begin{array}{c}\text { System } \\
\text { reading } \\
\text { (feet) }\end{array}$ & $\begin{array}{c}\text { 2 } \\
\text { Difference } \\
\text { (feet) }\end{array}$ & $\begin{array}{c}\text { Percent } \\
\text { difference } \\
\text { (percent) }\end{array}$ \\
\hline 0.000 & 0.037 & 0.037 & - - \\
0.333 & 0.363 & 0.030 & 9.0 \\
10.000 & 10.022 & 0.022 & 0.22 \\
20.000 & 20.001 & 0.001 & 0.005 \\
30.000 & 29.977 & -0.023 & -0.08 \\
40.000 & 39.955 & -0.045 & -0.11 \\
50.000 & 49.930 & -0.070 & -0.14 \\
55.000 & 54.922 & -0.078 & -0.14 \\
50.000 & 49.933 & -0.067 & -0.13 \\
40.000 & 39.950 & -0.050 & -0.12 \\
30.000 & 29.966 & -0.034 & -0.11 \\
20.000 & 19.981 & -0.019 & -0.10 \\
10.000 & 10.007 & 0.007 & 0.07 \\
0.333 & 0.353 & 0.020 & 6.0 \\
0.000 & 0.017 & 0.017 & - \\
\hline
\end{tabular}

1 A deadweight tester is a pressure standard for calibrating pressure transducers in which known pneumatic pressures are generated by means of freely balanced (dead) weights loaded on a calibrated ball.

2

Difference equals Endeco reading minus deadweight-tester reading. The negative sign indicates that the system tested recorded a value that was lower than the standard (deadweight tester). 
Table 9.--Test results of the Endeco mode1 1029 solid-state memory water-level recorder, May 28, 1987

(During the calibration test, the surface unit was at $25 \pm 2{ }^{\circ} \mathrm{C}$, and the subsurface sensor unit was in a water bath at a constant temperature of $45 \pm 0.2{ }^{\circ} \mathrm{C}$. The pressure was applied to the subsurface sensor unit using the deadweight tester.)

\begin{tabular}{|c|c|c|c|}
\hline $\begin{array}{c}{ }^{1} \text { Deadweight } \\
\text { tester } \\
(\text { feet })\end{array}$ & $\begin{array}{l}\text { System } \\
\text { reading } \\
\text { (feet) }\end{array}$ & $\begin{array}{c}{ }^{2} \text { Difference } \\
\text { (feet) }\end{array}$ & $\begin{array}{l}\text { Percent } \\
\text { difference } \\
\text { (percent) }\end{array}$ \\
\hline $\begin{array}{r}0.000 \\
0.333 \\
10.000 \\
20.000\end{array}$ & $\begin{array}{r}0.036 \\
0.357 \\
10.022 \\
20.008\end{array}$ & $\begin{array}{l}0.036 \\
0.024 \\
0.022 \\
0.008\end{array}$ & $\begin{array}{l}7 .- \\
7.2 \\
0.22 \\
0.04\end{array}$ \\
\hline $\begin{array}{l}30.000 \\
40.000 \\
50.000 \\
55.000\end{array}$ & $\begin{array}{l}30.125 \\
39.967 \\
49.937 \\
54.928\end{array}$ & $\begin{array}{r}0.125 \\
-0.033 \\
-0.063 \\
-0.072\end{array}$ & $\begin{array}{r}0.42 \\
-0.08 \\
-0.13 \\
-0.13\end{array}$ \\
\hline $\begin{array}{l}50.000 \\
40.000 \\
30.000 \\
20.000\end{array}$ & $\begin{array}{l}49.942 \\
39.966 \\
29.978 \\
19.991\end{array}$ & $\begin{array}{l}-0.058 \\
-0.034 \\
-0.022 \\
-0.009\end{array}$ & $\begin{array}{l}-0.12 \\
-0.08 \\
-0.07 \\
-0.04\end{array}$ \\
\hline $\begin{array}{r}10.000 \\
0.333 \\
0.000\end{array}$ & $\begin{array}{r}10.010 \\
0.366 \\
0.024\end{array}$ & $\begin{array}{l}0.010 \\
0.033 \\
0.024\end{array}$ & $\begin{array}{l}0.10 \\
9.9 \\
\ldots\end{array}$ \\
\hline
\end{tabular}

1 A deadweight tester is a pressure standard for calibrating pressure transducers in which known pneumatic pressures are generated by means of freely balanced (dead) weights loaded on a calibrated ball.

2 Difference equals Endeco reading minus deadweight-tester reading. The negative sign indicates that the system tested recorded a value that was lower than the standard (deadweight tester). 
Table 10.--Test results of the Endeco model 1029 solid-state memory water-1eve1 recorder, May 29, 1987

(During the calibration test, the surface unit was at $25 \pm 2{ }^{\circ} \mathrm{C}$, and the subsurface sensor unit was in a water bath at a constant temperature of $15 \pm 0.2{ }^{\circ} \mathrm{C}$. The pressure was applied to the subsurface sensor unit using the deadweight tester.)

\begin{tabular}{cccc}
\hline $\begin{array}{c}1 \text { Deadweight } \\
\text { tester } \\
(\text { feet) }\end{array}$ & $\begin{array}{c}\text { System } \\
\text { reading } \\
\text { (feet) }\end{array}$ & $\begin{array}{c}\text { 2 Difference } \\
\text { (feet) }\end{array}$ & $\begin{array}{c}\text { Percent } \\
\text { difference } \\
\text { (percent) }\end{array}$ \\
\hline 0.000 & 0.071 & 0.071 & -- \\
0.333 & 0.404 & 0.071 & 21 \\
10.000 & 10.057 & 0.057 & 0.57 \\
20.000 & 20.034 & 0.034 & -0.17 \\
30.000 & 30.007 & 0.007 & -0.23 \\
40.000 & 39.986 & -0.014 & -0.04 \\
50.000 & 49.951 & -0.049 & -0.10 \\
55.000 & 54.933 & -0.067 & -0.12 \\
50.000 & 49.941 & -0.059 & -0.12 \\
40.000 & 39.964 & -0.036 & -0.09 \\
30.000 & 29.985 & -0.015 & -0.05 \\
20.000 & 20.001 & 0.001 & 0.005 \\
10.000 & 10.020 & 0.020 & 0.20 \\
0.333 & 0.372 & 0.039 & 12 \\
0.000 & 0.039 & 0.039 & $\cdots$ \\
\hline
\end{tabular}

1 A deadweight tester is a pressure standard for calibrating pressure transducers in which known pneumatic pressures are generated by means of freely balanced (dead) weights loaded on a calibrated ball.

2 Difference equals Endeco reading minus deadweight-tester reading. The negative sign indicates that the system tested recorded a value that was lower than the standard (deadweight tester). 
Table 11.--Test results of the Endeco model 1029 solid-state memory water level recorder, June 2, 1987

(During the calibration test, the surface unit was at $25 \pm 2{ }^{\circ} \mathrm{C}$, and the subsurface sensor unit was in a water bath at a constant temperature of $5 \pm 0.2{ }^{\circ} \mathrm{C}$. The pressure was applied to the subsurface sensor unit using the deadweight tester.)

\begin{tabular}{|c|c|c|c|}
\hline $\begin{array}{c}{ }^{1} \text { Deadweight } \\
\text { tester } \\
\text { (feet) }\end{array}$ & $\begin{array}{l}\text { System } \\
\text { reading } \\
\text { (feet) }\end{array}$ & $\begin{array}{c}{ }^{2} \text { Difference } \\
\text { (feet })\end{array}$ & $\begin{array}{l}\text { Percent } \\
\text { difference } \\
\text { (percent) }\end{array}$ \\
\hline $\begin{array}{r}0.000 \\
0.333 \\
10.000 \\
20.000\end{array}$ & $\begin{array}{r}0.177 \\
0.396 \\
10.045 \\
20.029\end{array}$ & $\begin{array}{l}0.177 \\
0.063 \\
0.045 \\
0.029\end{array}$ & $\begin{array}{l}19 \\
0.45 \\
0.145\end{array}$ \\
\hline $\begin{array}{l}30.000 \\
40.000 \\
50.000 \\
55.000\end{array}$ & $\begin{array}{l}30.017 \\
40.000 \\
49.966 \\
54.953\end{array}$ & $\begin{array}{r}0.017 \\
0.000 \\
-0.034 \\
-0.047\end{array}$ & $\begin{array}{r}0.06 \\
0.00 \\
-0.07 \\
-0.08\end{array}$ \\
\hline $\begin{array}{l}50.000 \\
40.000 \\
30.000 \\
20.000\end{array}$ & $\begin{array}{l}49.962 \\
39.983 \\
29.996 \\
20.019\end{array}$ & $\begin{array}{r}-0.038 \\
-0.017 \\
-0.004 \\
0.019\end{array}$ & $\begin{array}{r}-0.08 \\
-0.04 \\
-0.01 \\
0.95\end{array}$ \\
\hline $\begin{array}{r}10.000 \\
0.333 \\
0.000\end{array}$ & $\begin{array}{r}10.037 \\
0.392 \\
0.056\end{array}$ & $\begin{array}{l}0.037 \\
0.059 \\
0.056\end{array}$ & $\begin{array}{c}0.37 \\
18 \\
.\end{array}$ \\
\hline
\end{tabular}

1 A deadweight tester is a pressure standard for calibrating pressure transducers in which known pneumatic pressures are generated by means of freely balanced (dead) weights loaded on a calibrated ball.

2

Difference equals Endeco reading minus deadweight-tester reading. The negative sign indicates that the system tested recorded a value that was lower than the standard (deadweight tester). 


\section{CONCLUSIONS}

Qualification tests conducted in the environmental chamber at the HIF's Test and Evaluation laboratory determined that the Leupold and Stevens water-level sensing system, consisting of the PG-III pulse generator, Telemark II encoder, and the environmental modem met or surpassed the Survey's minimum qualification standards for the daily-discharge station classification. Qualification tests conducted in the environmental chamber at the HIF's Test and Evaluation laboratory determined that the Endeco model 1029 solid-state memory water-level recorder systems met or surpassed the Survey's minimum qualification standards for the special-case station classification. These systems have been added to the Qualified Products List for water-level sensing instrument systems as a result of these tests. HIF-I-1 specifications were used for qualification evaluation.

This report and other test reports in this series do not make recommendations as to the best instrument system for any given application. They do, however, provide a list of system features, a description of the instrument systems, a summary of test procedures, and test results to assist users in selecting a particular system, or systems, that best fits a particular set of field conditions. 


\section{SELECTED REFERENCES}

Buchanan, T.J., and Somers, W.P., 1968, Stage measurement at gaging stations: U.S. Geological Survey Techniques of Water-Resources Investigations, Book 3, Chapter A7, 28 p.

Federal Communications Commission, 1986, Code of Federal Regulations for Telecommunication: Federal Communications Commission, v. 47, pt. 40-69, $365 \mathrm{p}$.

General Services Administration, 1984, Federal acquisition regulations, qualified products: General Services Administration, v. 1, p. 9.2, 9.4-9.6.

Holland, R.R., and Rapp, D.H., 1988, Results of qualification tests on water-level sensing instrumentation, $1986,34 \mathrm{p}$.

Kennedy, E.J., 1983, Computation of continuous records of streamflow: U.S. Geological Survey Techniques of Water-Resources Investigations, Book 3, Chapter A13, $53 \mathrm{p}$.

Rantz, S.E., and others, 1982, Measurement and computation of streamflow: Volume 1, measurement of stage and discharge: U.S. Geological Survey Water-Supply Paper 2175, p. 32-34.

Rapp, D.H., 1982, Specification for procurement of water-level sensing instrumentation, specification number HIF-I-1: U.S. Geological Survey Open-File report $82-89,24$ p.

Rapp, D.H., McDonald, B.L., and Hughes, R.M., 1984, Results of qualification tests on water-leve1 sensing instruments: U.S. Geological Survey Open-File Report 85-199, 47 p.

-..- 1985, Results of qualification tests on water-level sensing instruments, 1984-85: U.S. Geological Survey Open-File Report 85-489, 18 p. 


\section{GLOSSARY}

ASCII. The American Standard Code for Information Interchange uses serial communications protocol, an 8-bit character code for communication to com. puters.

Daily-discharge station. A daily-discharge station is a site where no more than a 0.05 -percent error of full-scale is allowed.

Deadweight tester. A pressure standard for calibrating pressure transducers in which known pneumatic pressures are generated by means of freely balanced (dead) weights loaded on a calibrated ball.

Drift, stability. Gradual shift or change in the output over a period of time due to change or aging of circuit components (source IEEE Standard Dictionary of Electrical and Electronics Terms).

Encoder. An encoder receives impulses from an analog measuring device, converts them to a digital representation, and stores this representation in its internal memory.

Error. Error in stage output is defined as the difference between the true water-surface height above a given datum and that measured simultaneously by the water-level sensing system.

Instrument package size and weight. The requirements to house the instrument system including any of the required interface hardware, nitrogen gas tanks, pressure system, power supply, and batteries are classified as follow:

A. Smaller than 18 inches long by 12 inches wide by 18 inches high and no single component weighs more than 25 pounds.

B. Larger than size A but smaller than 36 inches long by 18 inches wide by 36 inches high and complete system weighs less than 50 pounds.

C. Larger than size B but smaller than 4.0 feet long by 3.0 feet wide by 8.0 feet high and complete system weighs less than 75 pounds.

D. Larger than size $C$ and (or) weighs more than 75 pounds.

NOTE: The weight listed in items A through $D$ above excludes the weight of a nitrogen gas tank in cases where a tank is required.

RS-232C. The Electronics Industry Association's (EIA) recommended standard, defining the electrical characteristics and physical specifications for serial transmission.

Special-case station. A special-case station is a site where a 0.5 -percent error of full-scale is acceptable. 


\section{APPENDIX I.--REPRINT OF COMPARISON OF INSTRUMENT SYSTEM FEATURES}

FROM THE THREE PREVIOUS QUALIFIED PRODUCTS LIST

REPORTS ON WATER-LEVEL SENSING INSTRUMENTS

For the reader's convenience, the first table of Open-File Reports 85-199, 85-489, and 88-193 is included. These reports concern instruments tested between 1983 and 1986 . 
Open-File report $85-199$

Table 1.--Comparison of instrument system features

\begin{tabular}{|c|c|c|c|c|c|}
\hline $\begin{array}{l}\text { Instrument Company and } \\
\text { Model Name }\end{array}$ & $\begin{array}{c}\text { Fluidgage } \\
\text { HY 50FT } \\
\text { H2O }\end{array}$ & $\begin{array}{c}\text { Golden River } \\
\text { Waterman } \\
\text { Model } 502\end{array}$ & $\begin{array}{l}\text { ISCO } \\
\text { Model } \\
2300\end{array}$ & $\begin{array}{l}\text { Sarasota } \\
\text { Upward } \\
\text { Looking }\end{array}$ & $\begin{array}{l}\text { STACOM }^{J} \\
\text { Manometer }\end{array}$ \\
\hline Features $^{b}$ & & & & & \\
\hline $\begin{array}{l}\text { Station Typec } \\
\text { dally discharge (daily) } \\
\text { or special (special) }\end{array}$ & $d^{1} i_{\text {special }}$ & dally & daily & special & dally \\
\hline $\begin{array}{l}\text { System error as tested } \\
\text { (feet) }\end{array}$ & $\begin{array}{l}-.12 \text { to } \\
\quad+.03\end{array}$ & +0.02 & +0.01 & +0.05 & +0.01 \\
\hline $\begin{array}{l}\text { Sensor Type - Float (F) } \\
\text { Manometer (M) } \\
\text { or Transducer (T) }\end{array}$ & $\mathbf{M}$ & $\mathbf{F}$ & $\mathbf{T}$ & $\mathbf{T}$ & $\mathbf{M}$ \\
\hline $\begin{array}{l}\text { Stilling well (SW) } \\
\text { or orifice (OR) }\end{array}$ & OR & SW & ${ }^{e_{S W}}$ & SW & $\mathrm{OR}$ \\
\hline $\begin{array}{l}\text { Sensor distance } \\
\text { to recorder (feet) }\end{array}$ & 1600 & 300 & 100 & 300 & 1600 \\
\hline $\begin{array}{l}\text { Recommended range } \\
\text { In stage (feet) }\end{array}$ & $f_{0-50}$ & $0-215$ & $.08-12$ & $\mathrm{~B}_{2-30}$ & $\begin{array}{c}0-35 \text { or } \\
0-50\end{array}$ \\
\hline Affected by sediment & Yes & Yes & Yes & Yes & Yes \\
\hline $\begin{array}{l}\text { Power requirement } \\
\text { (volts dc, ac) }\end{array}$ & 12,120 & $h_{6}$ & 12,120 & 12 & 12 \\
\hline $\begin{array}{l}\text { Instrument weight } \\
\text { (1bs) }\end{array}$ & 30 & 11 & 15.5 & 22 & 50 \\
\hline Instrument size & B & A & $\mathbf{A}$ & $\mathbf{A}$ & C \\
\hline Shelter required & Yes & Yes & Yes & No & Yes \\
\hline $\begin{array}{l}\text { Operating range in air } \\
\text { temperature }\left({ }^{C} \mathrm{C}\right)\end{array}$ & -40 to 65 & -20 to 65 & -17 to 65 & 0 to 65 & -40 to 65 \\
\hline Internal data memory & No & Yes & Yes & Yes & No \\
\hline Data output to & $A D R$ & ASCII & ASCII & ASCII & $A D R$ \\
\hline
\end{tabular}

a The use of brand names in this report is for identification purposes only and does not constitute endorsement by the U.S. Geological Survey. (Appendix D of Open-File Report 85-199 gives company names and addresses.) See glossary for definition of terms.

c Recommended use, based on maximum allowable error. (For more information, consult Appendix C of Open-File Report 85-199.)

d Shelter temperature should be maintained above $0{ }^{\circ} \mathrm{C}$ to reduce temperature induced errors to 0.03 foot.

e Can mount sensor in culvert pipe without stilling well. A vertical or sloping stilling well is recommended for open channel flow sites.

f Only the ranges 0 to 10 and 50 feet were tested. Manufacturer claims ranges to 225 feet.

8 Only the range 2 to 15 feet was tested. Manufacturer claims range to 164 feet, but we recommend range to 30 feet.

h Two internal rechargeable batteries.

1 May not be acceptable for daily discharge stations that have very sensitive controls.

j The STACOM manometer was removed from the QPL May 1988. 
Open-File report $85-489$

Table 1.--Comparison of instrument system features.

\begin{tabular}{|c|c|}
\hline $\begin{array}{l}\text { Instrument Company } \\
\text { ModeI name }\end{array}$ & $\begin{array}{l}\text { Tavis Corporation } \\
\text { Insulated Transducer } \\
\text { Model No. SPCL }\end{array}$ \\
\hline \multicolumn{2}{|l|}{ Features } \\
\hline $\begin{array}{l}\text { Station Type } \\
\text { daily discharge (daily) } \\
\text { or special (special) }\end{array}$ & Special \\
\hline $\begin{array}{l}\text { System difference from } \\
\text { standard reference (feet) }\end{array}$ & -.08 to +.06 \\
\hline $\begin{array}{l}\text { Sensor Type - } \\
\text { Pressure Transducer (PT) } \\
\text { Ultrasonic Transducer (UT) }\end{array}$ & $\mathrm{PT}$ \\
\hline $\begin{array}{l}\text { Stilling well (SW) } \\
\text { or orifice (OR) }\end{array}$ & $\mathrm{OR}$ \\
\hline $\begin{array}{l}\text { Maximum sensor distance } \\
\text { to recorder (feet) }\end{array}$ & 1600 \\
\hline $\begin{array}{l}\text { Recommended range } \\
\text { in water-level (feet) }\end{array}$ & 0 to 34.7 \\
\hline Affected by sediment & Yes \\
\hline $\begin{array}{l}\text { Power requirement } \\
\text { (volts dc, ac) }\end{array}$ & 10 to $32 \mathrm{vdc}$ \\
\hline $\begin{array}{l}\text { Instrument weight } \\
\text { (1bs) }\end{array}$ & 3.5 \\
\hline $\begin{array}{l}\text { Instrument size } \\
\text { (See Glossary) }\end{array}$ & A \\
\hline Shelter required & Yes \\
\hline $\begin{array}{l}\text { Operating range in air } \\
\text { temperature }\left({ }^{8}\right)\end{array}$ & -10 to 65 \\
\hline Internal data memory & No \\
\hline Data output, analog & 0 to $5 \mathrm{vdc}$ \\
\hline
\end{tabular}




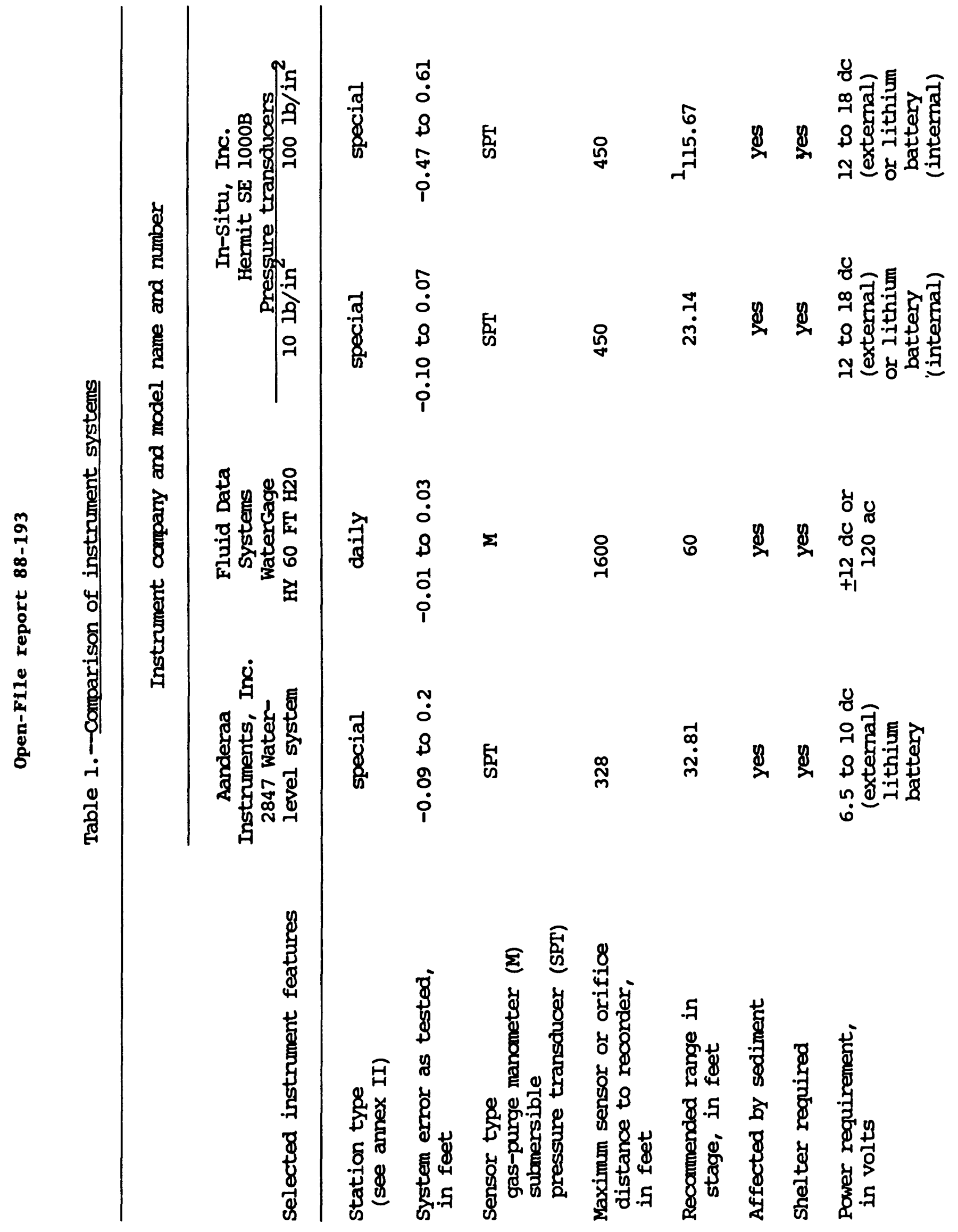




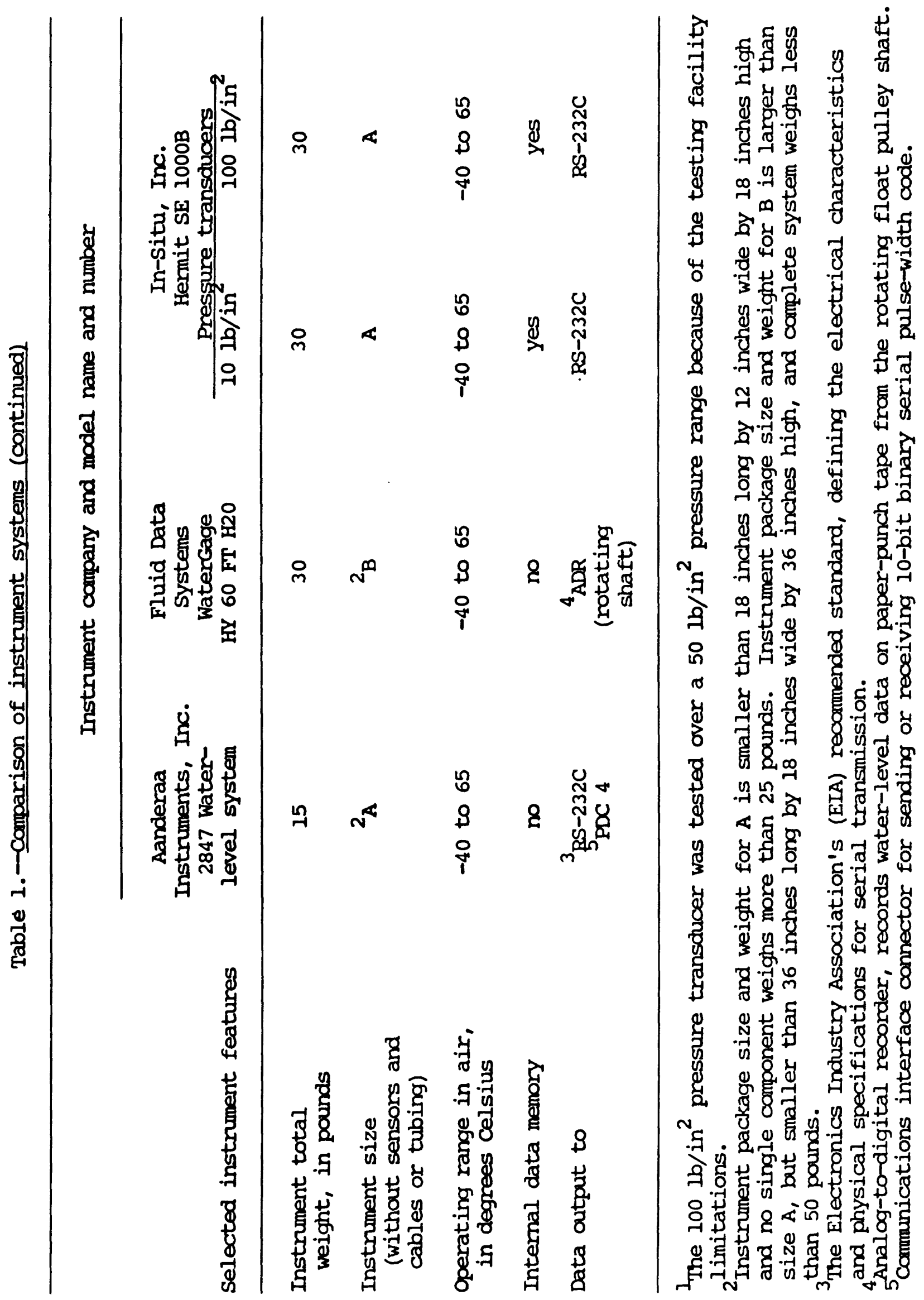


APPENDIX II.--QUALIFIED PRODUCTS LIST FOR WATER-LEVEL

SENSING INSTRUMENTS, OCTOBER 1987

Daily-Discharge Stations

Type: Encoder Shaft (Electronic)

Golden River Encoder, Model Number 502

Golden River Corporation, 7672 Standish Place, Rockville, MD 20855

Type: Manometer (Mechanical)

1 WaterGage, Model Numbers HY 10 FT H20 to 60 FT H20

Fluid Data Systems, 7370 Opportunity Road, San Diego, CA 92111

Type: Transducer, Pressure (Submersible)

ISCO, Model Number 2500

ISCO, Inc. Environmental Division, 531 Westgage Blvd.,

Lincoln, NB 68501

2ype: Encoder Shaft (Electronic)

2 Leupold and Stevens PG-III Pulse Generator, Telemark II Encoder, and the Environmental Modem

Leupold and Stevens, Inc., P.0. Box 688, Beaverton, OR 97075

\section{Special-Case Stations}

Type: Acoustic (Contact)

Sarasota Upward Looking

Sarasota Automation, Inc., 1500 N. Washington Blvd., Sarasota, FL 33577

Type: Transducer, Pressure (Nonsubmersible)

Tavis Insulated Transducer, Model Number SPCL

Tavis Corporation, 3636 Highway 49, Mariposa, CA 95338

Type: Transducer. Pressure (Submersible)

1 Aanderaa Instruments; Water-Level Sensor 2847, Battery Pack 2987 and Sensor Plug-in Board 3010

Aanderaa Instruments Inc., 30 F Commerce Way, Woburn, MA 01801

1. Type: Transducer. Pressure (Submersible)

1 Hermit Environmental Data Logger, Model SE 1000B, 10 and $100 \mathrm{lb} / \mathrm{in}^{2}$

Pressure Transducers

In-Situ Inc., 210 South Third Street, P.O. Box I,

Laramie, WY 82070-0920

2 Type: Transducer. Pressure (Submersible)

Endeco Mode1 1029 SSM Water-Leve1 System

Endeco, Inc., 13 Atlantis Drive, Marion, MA 02738-0860

1 New addition to QPL December 1986.

2 New addition to QPL December 1987. 
Systems accuracy for daily-discharge and special-case stations to meet minimum performance requirements are taken from specification report (Rapp, 1982).

Daily-Discharge Stations

\begin{tabular}{cc}
\hline $\begin{array}{c}\text { Range in } \\
\text { stage } \\
\text { (feet) }\end{array}$ & $\begin{array}{c}\text { Maximum allowable } \\
\text { error } \\
\text { (feet) }\end{array}$ \\
\hline 0 to 10 & \pm 0.005 \\
0 to 20 & \pm 0.010 \\
0 to 35 & \pm 0.018 \\
0 to 50 & \pm 0.025 \\
0 to 100 & \pm 0.050 \\
0 to 200 & \pm 0.100 \\
greater than 200 & \pm 0.100 \\
\hline
\end{tabular}

Allowable full-scale error is 0.050 percent for all ranges less than 200 feet, except for shaft encoders. The maximum allowable error for shaft encoders is \pm 0.005 feet of the indicated reading.

Special-Case Stations

\begin{tabular}{cc}
\hline $\begin{array}{c}\text { Range in } \\
\text { stage } \\
\text { (feet) }\end{array}$ & $\begin{array}{c}\text { Maximum allowable } \\
\text { error } \\
\text { (feet) }\end{array}$ \\
\hline 0 to 10 & \pm 0.050 \\
0 to 20 & \pm 0.100 \\
0 to 35 & \pm 0.180 \\
0 to 50 & \pm 0.250 \\
0 to 100 & \pm 0.500 \\
0 to 200 & \pm 1.000 \\
greater than 200 & \pm 1.000 \\
\hline
\end{tabular}

Allowable full-scale error is 0.50 percent for all ranges less than 200 feet, except for shaft encoders. The maximum allowable error for shaft encoders is \pm 0.05 feet of the indicated reading. 